\title{
ANAYASACILIK BAĞLAMINDA İSLAMI ANAYASACILIK KAVRAMI VE MEDİNE VESİKASI
}

\author{
In the Context of the Constitutionalism the Islamic Constitutionalism \\ Concept and the Medina Document
}

\section{Erdoğan KESKİ**}

\section{ÖZ}

$\mathrm{Bu}$ çalışmada, liberalizmin bir eseri olan anayasacılık düşüncesinin yanı sıra İslami anayasacılık fikrinin mümkün olup olmadığ 1 incelenmektedir. Nitekim anayasacılık, liberal düşünürler ve fikirler etrafında ortaya çıkmıştır. Dolayısıyla bir başka ideoloji ya da inanca özgü bir anayasacılıktan bahsedilebilir mi sorusu, cevaba muhtaç bir sorudur. Çalışmada ele alınan diğer bir ana konu ise birçok yazar tarafından anayasa olarak ifade edilen ve değerlendirilen Medine Vesikası'dır. Anayasa kavramının anlamı, Vesika'nın kabul edildiği dönem şartları ve ortaya çıkışı; bu yazarların iddialarının doğruluğunun tespiti açısından değerlendirilmesi gereken hususlardır. Zira anayasa kavramı, anayasacılıktan bağımsız düşünülemeyeceğinden gerek İslami anayasacılık söylemleri gerek Vesika'nın anayasa olduğuna dair iddialar, birbirinden bağımsız değildir. Bu nedenle çalışmada her iki konu birlikte incelenmiştir.

Çalışma İslami anayasacılık iddialarının ve Medine Vesikası'nın anayasa olduğuna dair iddiaların değerlendirilmesini ve konunun özünden ayrılmayarak bu fikirlerin yerinde olup olmadığının tespit edilmesini amaçlamaktadır. $\mathrm{Bu}$ bağlamda çalışmanın anayasacılık ve anayasa kavramlarının anlaşılması açısından yeni bir soluk getirmeyi amaçladığı ifade edilebilir.

Anahtar Kelimler: Anayasacılık, Anayasa, Siyasi iktidar, İslami Anayasac1lı, Medine Vesikası.

Makale Geliş Tarihi: 23.10.2020, Makale Kabul Tarihi: 25.05.2021.

* Araştırma Görevlisi, Erzincan Binali Yıldırım Üniversitesi Hukuk Fakültesi, Anayasa Hukuku Anabilim Dalı, (erdogan.keskin@erzincan.edu.tr, ORCID: 0000-0003-4718-4655) 


\section{ABSTRACT}

This study examines the idea of constitutionalism, which is a work of liberalism, as well as whether the idea of Islamic constitutionalism is possible. Indeed, constitutionalism has emerged around liberal thinkers and ideas. Therefore, the question of whether any other ideology or faith-specific constitutionalism can be mentioned is a question that is in need of answers. Another main topic addressed in the study is the Medina Document, which is expressed and evaluated by many authors as a constitution. The meaning of the concept of the Constitution, the conditions and the emergence of the period when the document was accepted; these are the points that should be evaluated in order to determine the accuracy of the authors' claims. Because the concept of constitution cannot be considered independent from constitutionalism, both the Islamic constitutionalism discourses and claims that the document is a constitution are not independent from each other. For this reason, both issues were examined together in the study.

The study aims to evaluate both the Islamic constitutionalism claims and the claims that the Medina Document is a constitution and to determine whether the claims are in place without leaving the core of the subject. In this context, it is not an exaggerationto state that the study aims to bring a new breath to understanding the concepts of constitutionalism and constitution.

Keywords: Constitutionalism, Constitution, Political Power, Islamic Constitutionalism, The Medina Document.

\section{Gíriș}

Modern çağa ve liberal düşünceye ait olan anayasacılık düşüncesi, İslami anayasacılık ve sosyalist anayasacılık gibi çeşitli türlere ayrılmaktadır. Hatta antik dönemlere ait bazı devlet uygulamaları ve düşünceler de anayasacılık kapsamına dahil edilmeye çalışılmaktadır. Dolayısıyla anayasacılığın ne olduğunun anlaşılması, bu iddiaların doğruluğunun tespit edilmesinde önemli bir role sahiptir. Çalışmada ilk olarak, buna ilişkin kriterler belirlenecek ve İslami anayasacılıktan söz edilip edilemeyeceği sorusuna cevap aranacaktır.

Çalışmanın ikinci ana konusu olan Medine Vesikası ise anayasacılık paralelinde ele alınacak, Vesika'nın bir anayasa olup olmadığı incelenecektir. Zira anayasalar, anayasacılık sonucunda ortaya çıktığı kabul edilen kurallar bütünüdür. Eğer anayasalar anayasacılıkla ortaya çıkmışsa, Miladi 7. yüzyılda imzalanan Vesika'nın, anayasa olarak değerlendirilebilir olup olmadığı sorusu veya buna benzer sorular, çalışma kapsamında ele alınarak, özellikle 
Vesika'nın ortaya çıktığı siyasi ve dini koşullar da göz ardı edilmeden cevaplandırılmaya çalışılacaktır.

\section{I. İSLAMİ ANAYASACILIK}

\section{A. Genel Olarak Anayasacilık}

Anayasac1lık, birey hürriyetlerini korumak amaciyla egemenin ve siyasi iktidarın yetkilerinin sınırlandırılmasını ifade etmektedir ${ }^{1}$. Bu, hürriyetler karşısında siyasi iktidara güven duyulmamasının bir sonucudur². Kural koyma, yargılama ve yürütmeye ilişkin birçok yetkiyi elinde bulunduran siyasi iktidar karşısında savunmasız bir konumda olan bireyin baskılara direnmesi, anayasacılık düşüncesinin temelini oluşturmaktadır³ .

Anayasacılık düşüncesi, iktidarın bölünmesini gerektirir ${ }^{4}$. Bunun neticesinde her bir devlet organının da birbirlerini denetlemesi; bu organların önceden belirlenmiş, ilan edilmiş ve yetkilerini sınırlayan kurallara uygun hareket etmesi sağlanır ${ }^{5}$. Bu yolla iktidar ve devletin, bireyin özel hayatındaki varlığı olabildiğince azaltılır ve yetkilerin tek elde toplanması suretiyle keyfi bir yönetimin ortaya çıkması önlenir ${ }^{6}$.

1 Charles Howard Mcilwain, Constitutionalism: Ancient and Modern (e-book), Revised Edition, Cornell University Press, New York 1947, s. 22; Cata Backer, "From Constitution to Constitutionalism: A Global Framework for Legitimate Public Power Systems", Penn State Review, C. 113, S. 3, Y. 2009, s. 690; Carl Friedrich, Sinırlı Devlet (Çev. Mehmet Turhan), 2. Bs., Liberte Yayınları, Ankara 2014., s. 45; Mustafa Erdoğan, Anayasal Demokrasi, 13. Bs., Siyasal Kitabevi, Ankara 2017, s. 4.

2 Friedrich, s. 45. "If angels were to govern men, neither external nor internal controuls on government would be necessary." Türkçesi; "Eğer melekler insanları yönetmiş olsaydı, iktidarın ne iç ne de dış denetimine gerek kalmazdı." Bkz. James Madison, The Federalist (İçinde) (J. R. Pole Ed.), Hackett Publishing Company, Indianapolis/Cambridge 2005, No 51, s. 281.

3 Mehmet Turhan, "Anayasa ve Anayasac1lık", Amme Idaresi Dergisi, C. 27, S. 3, Y. 1994, s. 4; Mehmet Turhan, Anayasal Devlet, 3. Bs., Natural Yayıncılık, Ankara 2004, s. 67; Backer, s. 690; Friedrich, s. 22; Mcilwain, Constitutionalism, s. 22; Erdoğan Keskin, Anayasa Hukukunda Anayasacılık Düşüncesi, Adalet Yayınevi, Ankara 2020, s. 57.

4 Friedrich, s. 45; Erdoğan, Anayasal Demokrasi, s. 4. İlk kez Lord Acton, bu düşünceyi, "Güç yozlaştırır, mutlak güç mutlaka yozlaştırır." ("Power tends to corrupt, and absolute power corrupts absolutely.”), şeklinde ifade etmiştir. Konuya ilişkin bkz. Brian Martin, "Power Tends to Corrupt", Philosophy and Social Action, C. 16, S. 3, Y. 1990, s. 3-5; Lord Acton ve ifadesi için bkz. https://www.phrases.org.uk/meanings/absolute-power-corruptsabsolutely.html(E. 25.06.2020).

5 Erdoğan, Anayasal Demokrasi, s. 4; Zühtü Arslan, Anayasa Teorisi, Seçkin Yayıncılık, Ankara 2008, s. 21.

6 Erdoğan, Anayasal Demokrasi, s. 6; Mcilwain, Constitutionalism, s. 22. 
Anayasacılık düşüncesini, iktidarın sınırlandırılması amacına bağlı olarak ikiye ayıranlar da vardır ${ }^{7}$. Buna göre ilk olarak, antik anayasacıllk ve Orta Çağ anayasacılığı olarak adlandırılan uygulamaların klasik anayasacılık düşüncesini oluşturduğu iddia edilmektedir. Burada antik Yunan, Roma ve Orta Çağ anayasacılık düşünceleri, daha doğru bir ifadeyle "uygulamaları" ele alınır ${ }^{8}$. İkinci olarak da modern anayasacılıktan söz edilmektedir. Anayasacılığın bu türü ise, 17. ve 18. yüzyıl arasında gelişen ve birey hürriyetlerinin korunabilmesi için gereken araç ve ilkelerden oluşur?. Dolayısıyla anayasacılığın, diğer bir ifadeyle modern anayasacılığın 17. ve 18. yüzyılda, liberalizmin eseri olarak ortaya çıktığı söylenebilir ${ }^{10}$. Yaygın olarak da anayasacılık düşüncesi, bu anayasacılığı ifade etmek için kullanılmaktadır.

Friedrich'in de belirttiği gibi modern anayasacılık, bireyin özel alanının sınırlarını ve birey hürriyetlerini korumaya hizmet ettiğinden, klasik anayasacılık olarak ifade bulan uygulamalardan oldukça farklıdır ${ }^{11}$. Bununla birlikte iktidarın sınırlı olduğu fikrinin 17. ve 18. yüzyıllar arasında ilk kez ortaya çıktığını söylemek tam olarak doğru değildir ${ }^{12}$. Birçok toplumda ve inançta iktidarın sınırlandırılmasına ilişkin bazı araçların ve ilkelerin benimsendiği görülmektedir. Buna rağmen anayasacılık düşüncesinin temelini oluşturduğu iddia edilen klasik anayasacılık düşüncesinin mahiyetinin ne olduğu tartışmalıdır. Özellikle Friedrich, antik Yunan'da düşünürlerin bireysel hak ve hürriyetleri koruma amacından çok, siyasi

7 Erdoğan, Anayasal Demokrasi, s. 7; Dieter Grimm, Constitutionalism Past, Present and Future, 1. Bs., Oxford University Press, New York 2016., s. 43 vd.; Mcilwain, Constitutionalism, s. 23 vd. Anayasacılık düşüncesini ve hareketlerini 1789 öncesi ve sonrası olarak ikiye ayıran yazarlar da vardır. Konuya ilişkin incelemeler ve tartışmalar için bkz. Gisbert H. Flanz, XIX. Asır Avrupasında Anayasa Hareketleri (Çev. Necat Erder/Şerif Mardin/Aydın Sinanoğlu), 1. Bs., AÜSBF Yayınları/Müșterek Yayınlar, Ankara 1956, s. 828.

8 Bkz. Erdoğan, Anayasal Demokrasi, s. 6; Mcilwain, Constitutionalism, s. 23 vd.

9 Grimm, s. 42; Erdoğan, Anayasal Demokrasi, s. 12; Ayrıca bkz. Mcilwain, Constitutionalism, s. 1-22.

10 Mustafa Erdoğan, Anayasacılık-Parlamantarizm-Silahlı Kuvvetler, Siyasal Kitabevi, Ankara 1993, s. 3.

11 Friedrich, s. 64; Erdoğan, Anayasal Demokrasi, s. 13.

12 Bkz. Adil Şahin, "Siyasal Düşünceler Tarihinde "Sınırlı Devlet" Fikrinin Kadimliği ya da Genel Kamu Hukuku Bağlamında İnsan, Özgürlük ve Devlet İktidarı Algısında Evrilme", Gazi Üniversitesi Hukuk Fakültesi Dergisi, C. XV, S. 3, Y. 2011, s. 313. Bu yüzy1llara kadar, dini inanç, adalet ve tabii hukuk kurallarının varlığına duyulan güven veya kamu yararı gibi birçok nedenlerle; aynı zamanda çeşitli araçlarla iktidarın sınırlı olduğu düşüncesi kabul edilmiş̧tir. Dolayısıyla iktidarın sınırlı olduğu düşüncesinin köklerini eski dönemlerde de bulmak mümkündür. Konuya ilişkin ayrıca bkz. Şahin, s. 313. 
iktidarın ahlakî olgunluğa sahip olmasının gerekliliğini vurguladıklarını belirtmektedir ${ }^{13}$. $\mathrm{Bu}$ nedenle klasik anayasac1lı olarak belirtilen uygulamaların, modern anayasacılıktan ayrıldığını savunmaktadır ${ }^{14}$. Friedrich'in bu yaklaşımından hareketle, örneğin Roma'da görülen senatusun istikrarı sağlamaya hizmet ettiği düşünülünce ${ }^{15}$, klasik anayasacılık olarak tarif edilen düşüncenin modern anayasac1lıktan farklı olduğunu söylemek gerekir. Ayrıca benzer şekilde Mcilwain, parlamento gibi siyasi iktidarı denetleyen veya onunla yetki paylaşımı yapan organlar olsa da bu organların varlığının iktidarı denetlemek için yeterli olmadığını savunmaktadır ${ }^{16}$. Buna göre modern anayasacılığın klasik anayasacılık olarak adlandırılan uygulamalardan ayrılan yanı, birey hürriyetleri karşısında iktidarın sınırlandırılması amacının olmasıdır. Öyleyse bu kapsamda anayasacılık adına bir "klasik anayasacılık" ayrımı yapmanın veya bir tür oluşturmanın yerinde olmadığı açıktır.

Klasik anayasacılığın modern anayasacılık için bir temel oluşturduğunu, klasik ve modern anayasacılık arasında devam eden bir bağlantının olduğunu savunanlar da vardır. Örneğin Levy’e göre, modern anayasacılıktaki birçok özellik, klasik anayasacılıkta da bulunur. Devlet faaliyetlerini kısıtlayan üstün normlar, her iki düşüncede de mevcuttur ${ }^{17}$. Fransa' da monarşiye karş1 verilen mücadelenin sona erdirilmesi, modern ve sınırlayıcı kurallarla veya mahkemelerle yapılmamıştır ${ }^{18}$. Yazara göre, iktidarın sınırlandırılması, Fransa'nın klasik anayasacılık düşüncesinin açık bir devamıdır. Ayrıca Amerika Birleşik Devletleri'nde de iktidarın sınırlandırılması düşüncesinin kabul edilmesinin altında bu tür eski anlayışlar yatmaktadır ${ }^{19}$.

Kanaatimizce Levy'nin aksine, Friedrich'in yaklaşımı daha yerindedir. Zira tarihsel vakalar birbirini muhakkak etkiler. Toplumlar geçmişten gelen değerlerin üzerinde ilerler. Dolayısıyla anayasacılık düşüncesinin geçmişten gelen ilkelerden etkilenmesi inkâr edilemez. Fakat bu, tek başına anayasacılık

13 Friedrich, s. 54, 202-203; Erdoğan, Anayasal Demokrasi, s. 13.

14 Friedrich, s. 54, 202-203; Erdoğan, Anayasal Demokrasi, s. 13.

15 Eşref Küçük, "Eski Roma'da Cumhuriyet Dönemi Halk Meclisleri ve Yasa Yapım Süreçleri”, Hacettepe Hukuk Fakültesi Dergisi, C. 7, S. 1, Y. 2017, s. 203; Friedrich, s. 203; Erdoğan, Anayasal Demokrasi, s. 13.

16 Charles Howard Mcilwain, The High Court of Parliament and Its Supremacy, 1. Bs., Yale University Press, London 1921, s. 6.

17 Jacob T. Levy, "Montesquieu's Constitutionalism Legacies", Montesquieu and His Legacy (İçinde) (Rebecca E. Kingston Ed.), 1. Bs., Suny Press, Albany 2009, s. 3-4, https://papers.ssrn.com/sol3/papers.cfm?abstract_id=1117087(E. 25.06.2020).

18 Levy, s. 3-4

19 Levy, s. 3-4. 
düşüncesinin, klasik anayasacılık olarak ifade edilen uygulamaların devamı olduğunu göstermez ${ }^{20}$. Modern anayasacılık düşüncesi, daha doğru kullanımla anayasacılık, 17. yüzyılın bir ürünü, liberal düşüncenin sağladığı birikimlerin adeta bir eseridir.

\section{B. İslam Hukukunda İktidarın Sınırlılığı ve Anayasacılık}

İslam hukukunun başlıca iki kaynağı Kur'an ve sünnettir. Bu iki kaynak, istisnasız herkes için ve her şartta bağlayıcıdır. Kur'an ve sünnete uygun davranma zorunluluğu siyasi iktidarın da sınırlarını belirler. Zira Kur'an, İslam hukukundaki tüm mesele ve hükümlerin kaynağıdır. Kur'an'ın ilke ve hükümlerinin tatbiki olan sünnet de aynı şekilde İslam hukukunun diğer ana kaynağıdı2 ${ }^{21}$. Kur'an ve sünnette yer alan emir ve yasaklar, yöneticilerin de uyması gereken emir ve yasaklardır. Herkes gibi başta siyasi iktidar ve kamu personeli bu hükümlere itaat etmek zorundadır ve dolayısıyla sınırlanmış vaziyettedir.

İslam hukukunun bir diğer kaynağ ${ }_{1}$ olarak kabul edilen icma ${ }^{22}$ ile de devlet başkanının gerekliliği ortaya konulmuştur. Hz. Peygember'in vefatından sonra bir devlet başkanının olması gerektiği hususunda sahabe ve tabiin icma etmişlerdir ${ }^{23}$. Alimlerin bu konuda ittifak etmesinin sebebi devlet başkanının, insanların huzurlu ve güvenli bir hayat yaşayabilmeleri için temel ihtiyaç olduğunu düşünmeleridir. Onlar, bu hususta Nisa Suresi'nin 59. ayetini $^{24}$ de kendilerine delil olarak almışlardır ${ }^{25}$. Bu ayete dayanarak bir ihtiyaç olarak kabul edilen devlet başkanının ve ona itaatin sınırları noktasında İmam Şafii, bu itaatin kayıtsız şartsız olmadığına, devlet başkanıyla kurulan bu ilişkkinin, sınırları belirli bir itaat ilişkisi olduğuna dikkat çeker ${ }^{26}$. İmam Şafii'nin bu görüşü devlet başkanlığına kaynak olarak kabul edilen icmanın

20 Ayrica bkz. Keskin, s. 79-81.

21 Hayrettin Karaman, Mukayeseli İslam Hukuku, C. 1, 1. Bs, İz Yayıncılık, İstanbul 2013, s. 115.

22 İcma, Kur'an ve sünnetten sonra üçüncü temel kaynak olarak kabul edilir. Kur'an ve sünnette hakkında bir hükme yer verilmeyen olaylar da verilecek hüküm hakkında müçtehitlerin ittifak etmesi, yani aynı görüşte birleşmesi olarak tanımlayabiliriz. İcmanın tanımı ve şartları için ayrıca bkz. Y. Vehbi Yavuz, "İcma'ın Hakikati ve İslam Teşri'indeki Önemi”, İslam Hukuku Araştırmaları Dergisi, S. 3, Y. 2004, s. 86-89.

23 Hüseyin Çeliker, "İslâm Hukuku'nda Devlet Başkanlığı”, Ondokuz Mayıs Üniversitesi İlahiyat Fakültesi Dergisi, C. 26, S. 26-27, Y. 2008, s. 262.

24 Ayetin Türkçe meali şöyledir; "Ey iman edenler! Allah'a itaat edin, peygambere itaat edin, sizden olan ülü'l-emre de."

25 Çeliker, 260-262.

26 Şafii, Ebû Abdullah Muhammed b. İdris Kitabu'l-ümm, I-VIII, Beyrut, C. I, s. 170, (Aktaran: Çeliker, s. 261.) 
temel mantığında mevcuttur. Zira icma bir konuda verilecek hükme ilişkin, müçtehitlerin ittifak etmelerini, yani bir görüşün diğerine dayatılmadan, görüşlerin eleştiri ve düşünce açıklamasına müsait bir mecliste ve ortamda açığa çıkarılmasını ifade eder ${ }^{27}$. Bir fikıh meclisi kurulmadan ve yetkili kişiler sorunları bu meclise arz etmeden icmanın tamamlanamayacağı ileri sürülmektedir. Bu meclisin bağımsız ve devletlerin etkisinden uzak olması gerektiği üzerinde de durulmaktadır ${ }^{28}$. Böyle bir meclisin olması ve siyasi etkiden uzak bir şekilde İslam hukukuna uygun olarak birçok konuya ilişkin karar alınması, siyasi iktidarı sınırlandırır.

Kur'an ve sünnete uygun davranma zorunluluğu bağlamında diğer bir konu ise kadılık (mahkeme) ve şeyhülislamlık makamlarıdır. Bu makamlar, devlet başkanının sınırlandırılmasında ve üst norm olan Kur'an ve sünnete uygunluk denetimi yapılmasında önemli bir konuma sahiptir. İlk olarak devlet başkanlarının temel görevlerinden birisi şeriatın korunması olduğundan, şeriatın tatbik edilmesi, yargılamaya ilişkin kimseden emir almayan -bağımsız ve tarafsız- kadılar aracıllğıly sağlanmaktadır ${ }^{29}$. Hatta İslam inancında yargilanan kim olursa olsun yargilamaya müdahale edilememektedir. Özellikle ayet ve hadis hükümlerinin uygulanması söz konusu ise, kadı hiçbir emir ve talimatı dinlemek zorunda değildir ${ }^{30}$. İkinci olarak ise şeyhülislamlıktan bahsetmek gerekir. Örneğin Osmanlı Devleti'nde şeyhülislamın konumuna bakıldığında bir tür norm denetiminin yapıldığı görülür. Padişah'ın aldığı bazı kararlar ve koyduğu kurallara ilişkin Şeyhülislam'ın görüşünün alınmas ${ }^{31}$ gerekliliği, kanaatimizce bunu göstermektedir ${ }^{32}$.

27 Yavuz, s. 102.

28 Yavuz, s. 102.

29 İlber Ortaylı, Hukuk ve İdare Adamı Olarak Osmanlı Devleti'nde Kadı, Kronik Kitap, 7. Bs., İstanbul 2017, s. 60-61; Mehmet Yüksel, "Osmanlı Toplum Yapısında Şeyhülislamlık Makamına Bir Bakış”, MÜHFHAD Cevdet Yavuz'a Armağan, C. 22, S. 3, Y. 2016, s. 3493; Hasan Tahsin Fendoğlu, İslam ve Osmanlı Anayasa Hukukunda Yargl Bă̆ımsızlığı, 1. Bs., Beyan Yayınları, İstanbul 1996, s. 35. Konuyla alakalı Kur'an'da birçok ayet vardır. Örnek olarak Nisa Suresi'nin 135. ayeti gösterilebilir: "Ey iman edenler! Adaleti titizlikle ayakta tutan, kendiniz, ana-babanız ve akrabanı aleyhinde de olsa Allah için şahitlik eden kimseler olun."

30 Nisa Suresi, 58. ayet. "Şüphesiz Allah size emanetleri ehline vermenizi ve insanlar arasında hükmettiğiniz zaman adaletle hükmetmenizi emreder.”. Aynı yönde bkz. Fendoğlu, İslam ve Osmanlı, s. 35.

31 İsmail Hakkı Uzunçarşılı, Osmanlı Devleti'nin İlmiye Teşkilatı, 4. Bs., Türk Tarih Kurumu, Ankara 2014, s. 194; Yüksel, s. 3494.

32 İslam hukukunda zulmetmeye başlayan ve İslam kurallarını ihlal eden hükümdarın azledilebileceğine ve alimlerin iktidarın sınırlandırılmasındaki rolüne ilişkin bkz. Ayhan Ceylan, “İslam'da Siyasi İktidar”, Eய̈HFD, C. VII, S. 1-2, s. 101-102. 
Öte yandan İslam hukukunun temel kaynakları Kur'an ve sünnette herhangi bir devlet rejimi veya türü öngörülmemiştir ${ }^{33}$. Ancak İslam devletlerinin kuruldukları toplum yapıları ve kamu yararı, devletin yönetimi için belirleyici etken olmuştur ${ }^{34}$. Bu gelenekler ve sosyal şartlar, ilk olarak siyasi iktidarın tabii sınırını meydana getirmiştir.

Devlet teşkilatlanmasında bu geleneklerin yanı sıra devlet başkanı olabilmek için de aranan bazı şartlar vardır. Örneğin, Müslüman ve adil olmak bunlardan bazılarıdır ${ }^{35}$. Dolayısıyla devlet başkanı adaletle hükmetmeli, belirli ahlaki niteliklere sahip olmalı ve kamu düzenini bizzat sağlamalıdır ${ }^{36}$. Diğer bir ifadeyle İslam hukukuna göre, devlet yönetiminde yöneticiler adil olmalı ve genel maslahata göre hareket etmelidir ${ }^{37}$. Bu kaide Mecelle'nin 58. maddesinde de şöyle ifade edilmektedir: "Reaya üzerinde tasarruf maslahata menuttur." Buna göre, iktidar kamu yararına en uygun şekilde hareket etmek zorundadır ${ }^{38}$. Netice itibariyle yöneticilerin kamunun zararına yaptığ 1 işlemler geçerli değildir ${ }^{39}$. Dolayısıyla ilk olarak bu şartların devlet başkanı olacak kişilerde aranması; devlet başkanının kişisel arzu ve keyfi eylemleriyle değil, genel yarara uygun davranması zorunluluğu ve toplum yapısının gerekleri, iktidarın sınırlandırılmasını sağlayan hususlardandır. Aynı zamanda kamunun zararına hareket eden yöneticiye karşı direnmek de yönetilenler için bir haktır ${ }^{40}$.

İslam hukukunda önemli bir yere sahip olan ve iktidarın sınırını oluşturan prensipler arasında görebileceğimiz "şûra" prensibi de konumuz açısından oldukça önemlidir. Zira şûra doğrudan Kur'an'da övülmüştür ve bu isimli bir de sure vardır ${ }^{41}$. İslam hukukunda şûranın önemi, Hz. Peygamber'in uygulamasıyla da açıklanmıştır. Örneğin Uhud Savaşı'nda Hz. Peygamber, şehir savaşı $\mathrm{m} 1$ yoksa meydan savaşı $\mathrm{m} 1$ yapılacağ 1 konusunda istişarede

33 Konuya ilişkin kapsamlı değerlendirmeler için bkz. Taha Akyol, Türkiye'nin Hukuk Serüveni, 5. Bs., Doğan Kitap, İstanbul 2016, s. 21-24.

34 Abdurrahman Eren, Anayasa Hukuku Ders Notlarl, On İki levha Yayınc1lık, İstanbul 2018, s. 25.

35 Çeliker, s. 267, 271.

36 Sabri Şakir Ansay, Hukuk Tarihinde İslam Hukuku, 4. Bs., Turhan Kitabevi, Ankara 2002, s. 347; Çeliker, s. 294.

37 Çeliker, s. 267, 271. Bu konuda ayrıntılı bilgi için bkz. Ceylan, "İktidar".

38 Hocaeminefendizâde Ali Haydar Efendi, Dürer'ül- Hükkâm Şehru Mecelleti'l-Âhkam, C. I, 1. Bs., Diyanet İşleri Başkanlığı Yayınları, İstanbul 2016, s. 125-126; Cengiz İlhan, Günümüz Türkçe'siyle Mecelle, 2. Bs., Yetkin Yayınları, Ankara 2014, s. 52-53; Ansay (2002), s. 348.

39 Ali Haydar Efendi, s. 126.

40 Bkz. Ansay (2002), s. 348.

41 Şûra Suresi, 38. Ayet: “...Onların işleri de kendi aralarında bir istişare iledir...” 
bulunmuş; ancak bazı genç sahabelerin 1srarı üzerine kendisi de şehir savaşından yana olan $\mathrm{Hz}$. Peygamber, gençlerin isteğine uygun karar vermiştir $^{42}$. Dolayısıyla istişare, diğer ifadeyle şûra İslam hukukunun iki temel kaynağı olan Kur'an ve sünnette yer bulduğundan sonraki idareciler için de uyulması gereken bir prensip halini almıştı ${ }^{43}$.

İslam hukukunda iktidarın sınırını oluşturan başka bir husus da, devletin "zarurat-1 hamse" ismi verilen, bireylerin dinini, canını, aklını, neslini ve malını koruması zorunluluğudur ${ }^{44}$. Devlet iktidarının bu alanları ihlal etmemesi gerektiği gibi bunların korunması için olumlu edimde bulunması, İslami devlet geleneğinde kişinin temel hürriyetlerinin devlet için bir sınır olduğunu göstermektedir. Diğer bir ifadeyle İslam inancı ve hukuku bağlamında iktidarın konumuna bakıldığında, mutlak yetkilerle donatılmış bir iktidarla karşılaşmak oldukça zordur.

Ayrıca sınırlı iktidar bağlamında, İslam inancına ve devletlerine bakıldığında bireyleri koruyan ve iktidarı sınırlandıran birçok belge ve beyan mevcuttur ${ }^{45}$. Bu belgeler ve beyanlar vasıtasıyla inanç, ahlak ve ibadete ilişkin konular ele alınmış; yönetime ilişkin meseleler de göz ardı edilmemiştir. Örneğin Medine Vesikası bu tür belgelerin ilklerinden olduğu gibi belki de en önemlisidir. Yazılı bir anayasa (anayasal belge) olarak ifade edilen Medine Vesikası'nda, devlet iktidarı oluşturulmakta, yürütme ve yargı kuvvetlerine ilişsin konular düzenlenmektedirr ${ }^{46}$. Bunun yanı sıra anayasaların temel şartı

42 Bkz. Sabri Hizmetli, İslam Tarihi, Ankara Üniversitesi İlahiyat Fakültesi Yayınları, Ankara 1991, s. 161.

43 Prensibin geniş ölçekte değerlendirilmesi için bkz. Azizah al-Hibri, "Islamic Constitutionalism and the Concept of Democracy", Case Western Reserve Journal of International Law, C. 24, S. 1, Y. 1992, s. 21-24.

44 Konuya ilişkin bkz. Muhammed Ebu Zehra, İslam Hukuku Metodolojisi-Fıkıh Usûlü, (Çev. Abdulkadir Şener), 13. Bs., Fecr Yayınları, Ankara 2017, s. 238-239; Muhammed Al-Tahir İbn Ashur, Treatise on Maqasid al-Shari'ah, 1. Bs., Biddles, London-Washington 2006, s. $118 \mathrm{vd}$.

45 İslam tarihinde Miladi 622 tarihli Medine Vesikası, bireylerin hürriyetlerini, canlarını ve mallarını koruma altına alan yazılı bir belgedir. Aynı şekilde Hicri 10 (Miladi 632) yılında okunan Veda Hutbesi de bireylerin eşitliğini, kardeşliğini, canını, malını, ırzını, insan aklını ve kadının kutsallığını dünyaya haykıran bir başka beyandır. Veda Hutbesinin tam metni için bkz. http://ahmetsimsirgil.com/wp-content/uploads/2015/12/Veda-Hutbesi.pdf(E. 25.06.2020). Medine Vesikas1, Vesika'ya neden olan etkenler ve Vesika'ya hâkim olan ilkeler için ayrıca bkz. Abdurrahman Demirci, "Medine Vesikası: Oluşum Süreci ve Zimmet Anlaşmalarına Etkisi”, İstem, S. 19, Y. 2012, s. 260-268.

46 Karaman, s. 89. Vesika, kan ve kabile yerine iradeye bağlı olarak devlet oluşumunu sağlamıştır. Zira, Vesika bir sözleşme şeklinde ortaya çıkmıştır. Buna göre, Vesika'nın hükümlerine uymak isteyen bireyler veya gruplar, kurulan siyasi toplumun üyesi olarak bazı 
olan birey hürriyetleri de Vesika'ya konu edilmektedir ${ }^{47}$. Hürriyetlerin ve iktidarın oluşumunun yazılı bir belge ile güvence altına alınmış olması, bu belgeyi hukuk kurallarının önceden belirlenmesi anlamında önemli hale getirmektedir.

Burada kısaca belirtmek gerekirse, Kur'an ve sünnete mutlak surette uyulması zorunluluğu ile icma ve şûra gibi diğer birçok ilke, yargının tarafsız ve bağımsız olması gerekliliği, devlet başkanının belirlenmesine dair ilkeler, kamu yararı, idari gelenekler ve yazılı bir belge olan Vesika'nın ortaya koyduğu ilkeler; bir İslam devletinde iktidarın belirli yönlerden sınırlı olduğunu gösterir. Ancak tespit edilmesi gereken husus, iktidarın bu şekilde sınırlı olmasının "anayasacı1ık" olup olmadığıdır.

Anayasacılık, 17. ve 18. yüzyıllar arasında, liberalizmin eseri olarak ortaya çıkmıştır ${ }^{48}$; bu yüzyıllar arasında gelişen ve birey hürriyetlerinin korunabilmesi için gereken araç ve unsurlardan oluşmaktadır ${ }^{49}$. Anayasacılığın temel iki unsuru ise kuvvetler ayrıllı̆ ${ }^{50}$ ve hukukun üstünlüğüdür ${ }^{51}$. Bu bağlamda modern çağın gelişmelerinin ürünü olan bir düşüncenin kendisinden önceki dönemlere ilişkin bir kriter olması yerinde değildir. "Klasik anayasacılık" olarak ifade edilen uygulamalara yönelik açıklamalar, söz konusu yüzyıllara kadar ki İslami uygulamalar açısından da geçerlidir ${ }^{52}$.

Zira her ne kadar çeşitli prensiplerle iktidarın sınırlarının varlığından söz edilebilse de, birey hürriyetlerinin korunması ve iktidarın sınırlandırılması düşüncesinin gelişmemesi; birey otonomisinin korunmasına yönelik mekanizmaların henüz tesis edilememesi ${ }^{53}$; iktidara güvenilmemesi yerine iktidara itaat (biat) kültürünün devam etmesi gibi çeşitli hususların varlığı, İslam devleti ve hukuku kapsamında iktidarının sınırlarının anayasacılık yönünde gelişmediğini ve anayasacılık teşkil etmediğini gösterir. Her ne kadar

yükümlülükleri kabul etmiş ve siyasi toplum içerisinde de haklarının korunmasından yararlanma imkânı elde etmiştir. Bkz. age, s. 89.

47 Karaman, s. 89. Vesika'nın maddeleri için bkz. Karaman, s. 85-88.

48 Erdoğan, Anayasacılık, s. 3.

49 Grimm, s. 42; Erdoğan, Anayasal, s. 12; Ayrıca bkz. Mcilwain, Constitutionalism, s. 1-22.

50 Bkz. Friedrich, s. 45; Erdoğan, Anayasal, s. 4.

51 Bkz. Erdoğan, Anayasal, s. 4; Arslan, Anayasa, s. 21.

52 Bkz. Yukarıda I-A.

53 Kuvvetler ayrılığına, iktidarın denetimine ve bireylerin korunmasına ilişkin teorik ve kurumsal bir mekanizma kurulamamıştır. Bkz. Kemal Gözler, "İslâm Hukukunun Değeri: İslâm Hukuku, Batı Hukukuna Alternatif Olabilir mi?”, www.anayasa.gen.tr/islamhukuku.htm, Yayın: 16 Aralık 2019, (E. 25.06.2020). 
çeşitli yönlerden iktidar sınırlandırılmış olsa da burada iktidarı sınırlandıracak veya onu denetleyecek kurumlar mevcut değildir.

\section{MEDINE VESIKKASI: İLK YAZILI ANAYASA İDDİASI}

\section{A. Genel Olarak Anayasa Kavramı}

Anayasa kavramı, 18. yüzyılda anayasacılık düşüncesinin bir sonucu olarak ortaya çıkmıştır ${ }^{54}$. İktidarı sınırlandırmak için girişilen mücadelelerin başarılı olması, iktidarın kalıcı olarak sınırlandırılmasını ve doğuştan sahip olunan hakların muhafaza altına alınmasını gerekli kılmıştır. Başka bir ifadeyle anayasacılık, iktidarın sınırlarının tespit edilmesini ve iktidarı sınırlamaya hizmet eden ilkelerle birlikte, kurumların da bağlayıcı bir güce sahip olmasını gerekli kılar ${ }^{55}$. Bu nedenle, iktidarın yetkilerini ve devletin teşkilatını belirleyen, aynı zamanda bireylerin sahip olduğu hak ve hürriyetleri güvence altına alan yazılı metinler ortaya çımıştır ${ }^{56}$.

Anayasacılık hareketleri sonucunda ortaya çıkan İngiliz anayasal belgelerine, ilk yazılı anayasa olan 1787 Amerika Birleşik Devletleri Anayasası'na $^{57}$ ve 1791 Fransız Anayasası'na bakıldığında anayasa kavramının sahip olduğu anlama ulaşmak mümkündür. Örneğin iktidarı sınırlama amacına uygun olarak kabul edilen Amerika Birleşik Devletleri Anayasası'nda, kuvvetlerin birbirinden ayrılması esasına dayanan başkanlık hükümet sistemi ve federal sistem benimsenmektedir ${ }^{58}$. 1791 Fransız Anayasası'na bakıldığında ise İnsan ve Yurttaş Hakları Bildirisi'nin sağladığı güvenceler kadar olmasa da, kişi hak ve hürriyetlerinin güvence altına alındığı görülmektedir ${ }^{59}$. Buna göre anayasalar, genel anlamda iktidarı sınırlandıran, devletin temel teşkilatını kuran, hak ve hürriyetleri güvence altına alan

54 Eren, Anayasa Hukuku, s. 1; Ömer Anayurt, Anayasa Hukuku Genel Kısım, 2. Bs., Seçkin Yayıncılık, Ankara 2019, s. 39; Bertil Emrah Oder, Avrupa Birliği'nde Anayasa ve Anayasacılık, 1. Bs., Anahtar Kitaplar Yayınevi, İstanbul 2004, s. 37; Erdoğan Teziç, Anayasa Hukuku, 20. Bs., Beta Basım, İstanbul 2016, s. 161.

55 Friedrich, s. 45; Friedrich A. Hayek, The Constitution of Liberty, 1. Bs., The University of Chicago Press, Chicago 1978, s. 182.

56 Benzer yönde bkz. Eren, Anayasa Hukuku, s. 1; Anayurt, Anayasa Hukuku, s. 47.

57 Kemal Gözler, Anayasa Hukukunun Genel Esasları, 8. Bs., Ekin Yayınları, Bursa 2016, s. 69; Teziç, Anayasa, s. 160.

58 George Athan Billias, American Constitutionalism Heard Round the World 1776-1989, 1. bs., New York University Press, New York-London 2009, s. 34-38; David A. J. Richards, Foundations of American Constitutionalism, 1. bs., Oxford University Press, New YorkOxford 1989, s. 107; Friedrich, s. 209.

59 Server Tanilli, Dünyayı Değiştiren 10 Yıl, 2. bs., Adam Yayıncılık, İstanbul 1999, s. 84-85. 
kurallar bütünüdür ${ }^{60}$. Anayasal kuralların kanunlardan üstün olması da gerekli değildir. Anayasaların yazılı olmaması veya kodifiye edilmemiş ve geleneksel nitelikte olmaları mümkündür. Zira iktidarı sınırlandırmaya yönelik önemli düşüncelerin ortaya çıtığg ve mücadelelerin verildiği İngiltere'de anayasanın varlığı bu şekildedir ${ }^{61}$.

Her ne kadar anayasa kavramı ve ilk anayasalar bu tarihsel gelişim etrafında ortaya çıkmış olsa da anayasa kavramının karşıladığı anlamın bu döneme özgü olmadığına yönelik görüşler vardır. Dolayısıyla anayasa kavramının açıklanması sırasında modern dönem ve bu dönemden önceye ait durumlardan da bahsetmek yerinde olur.

İlk olarak, en eski toplumlardan beri devletin teşkilatlanmasını ve bireydevlet ilişkilerini konu alan yazılı veya yazısız kurallar mevcuttur ${ }^{62} . \mathrm{Bu}$, her toplum için kaçınılmazdır. Çünkü her toplumda siyasi iktidar mevcut olmuş; siyasi iktidarın oluşumu, yetkileri ve ilişkileri yazılı veya yazısız kurallarla belirlenmiştir. Buna doktrinde yaygın olarak geniş anlamda anayasa denilmektedir ${ }^{63}$. Öyleyse geniş anlamda anayasalar, devletin temel organları (yasama-yürütme ve yarg1) ile hak ve hürriyetleri konu alan kuralların bütünüdür ${ }^{64}$. Nihayet bu yaklaşıma göre bir kural, devletin temel organlarıyla ve haklarla ilgiliyse, geniş anlamda anayasa kuralıdır ${ }^{65}$. Örneğin İhtilal öncesinde, Fransa'da kralın uymak zorunda olduğu "Kralın Temel Kanunları" isimli devletin genel işleyişine ilişkin kurallar, bu minvalde değerlendirilebilirr ${ }^{66}$.

Ancak anayasalar, gelişen birey ve hürriyet olgusuyla birlikte iktidarı sınırlandırma düşüncesinin paralelinde ortaya çıkmıştır. Yani anayasalar, devlet teşkilatını kuran basit metinler değillerdir. Anayasaların varlık sebebinin altında ciddi bir anlam yatmaktadır. Bu nedenle "anayasa" kavramının idrakinin mümkün olabilmesi, anayasa kavramının ontolojik yönünün anlaşılmasında gizlidir. Eski toplumlarda devletin teşkilat yapısına ve birey-devlet ilişkisine ilişkin yazılı ya da yazısız kuralların olması, onların

60 Eren, Anayasa Hukuku, s. 4; Erdoğan, Anayasal Demokrasi, s. 3, 25; İbrahim O. Kaboğlu, Anayasa Hukuku Dersleri, 9. Bs., Legal Yayınc1lı, İstanbul 2014, s. 48; Hayek, The Constitution, s. 180, 182; Teziç, Anayasa, s. 161.

61 K. C. Wheare, Modern Anayasalar (Çev. Mehmet Turhan), Değişim Yayınları, İstanbul 1984, s. 1; Anayurt, Anayasa Hukuku, s.104-106.

62 Anayurt, Anayasa Hukuku, s. 100.

63 Anayurt, Anayasa Hukuku, s. 100-101; Gözler, Anayasa Hukuku, s. 49.

64 Anayurt, Anayasa Hukuku, s. 101; Gözler, Anayasa Hukuku, s. 49; Eren, Anayasa Hukuku, s. 4; Kaboğlu, Anayasa Hukuku, s. 11.

65 Gözler, Anayasa Hukuku, s. 49.

66 Teziç, Anayasa Hukuku, s. 160. 
anayasa olduğu anlamına gelmez. Zira ontolojik olarak anayasalardan söz etmemiz, 18. yüzyılda mümkün olmuştur. Bunun sebebi de birey karşısında sınırlandırılan iktidarın yeni pozisyonunun, hak ve hürriyetler için güvenceli olmasını sağlamaktır. Kanaatimizce, geniş anlamda anayasayı, "devletin temel organları ile hak ve hürriyetleri konu alan yazılı ve yazısız (sert veya yumuşak) kurallar bütünü" olarak tanımlarken, 18. yüzyıldan itibaren bireycilik kapsamında bireyi korumak ve iktidarı sınırlandırmak için kabul edilen kurallar olarak tarif etmek gerekir.

Öte yandan anayasa kavramı yaygın olarak geniş anlamıyla değil, dar anlamıla kullanılır ${ }^{67}$. Dolayısıyla ikinci olarak anayasanın dar anlamından bahsetmek gerekir. $\mathrm{Bu}$ anlamıyla anayasa, belli bir makam tarafindan oluşturulmuş, devletin temel organlarını ve işleyişini, birey hak ve hürriyetlerini konu alan yazılı kurallar bütünüdür ${ }^{68}$. Anayasanın bu tarifine uygun olarak ortaya çıkan ilk anayasa ise 1787 Amerika Birleşik Devletleri Anayasasidir ${ }^{69}$.

Bununla birlikte anayasa ismi verilsin ya da verilmesin o nitelikte görülen metinlerin anayasa olup olmadığının tespitinde metnin ismine değil, içeriğine bakmak gerekir. Bu gerçek, 26 Ağustos 1789'da ilan edilen "İnsan ve Yurttaş Hakları Bildirisi"sinin 16. maddesinde, "insan haklarinın

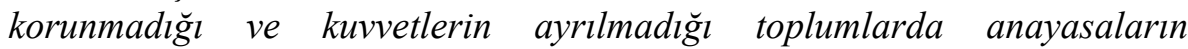
varlığından bahsedilemeyeceğ $i$ " şeklinde ifade edilmektedir ${ }^{70}$. Liberal anlayışın eseri olarak bir anayasanın varlı̆̆ı, en özet şekliyle insan haklarının korunması ve kuvvetlerin ayrılmasına bağlıdır. Nitekim kuvvetlerin ayrılmadığ 1 hallerde Montesquieu'nun da kabul ettiği üzere hürriyetler tehlikede demektir ${ }^{71}$.

67 Wheare, s. 3.

68 Anayurt, Anayasa Hukuku, s. 102-103; Eren, Anayasa Hukuku, s. 4. Gözler, dar anlamda anayasayı normlar hiyerarşinin üzerinde bulunan ve değiştirilmesi diğer basit kanunlardan farklı ve daha zor olan kurallar bütünü olarak tanımlamaktadır. Bkz. Gözler, Anayasa Hukuku, s. 49.

69 Bkz. Gözler, Anayasa Hukuku, s. 69;

70 Erdoğan, Anayasal Demokrasi, s. 22; Muhammet Emin Ruhi, 1789 Fransiz Devrimi Birinci Kitap, 1. Bs., On İki Levha Yayınc1lık, İstanbul 2018, s. 70; Turhan, Anayasal Devlet, s. 69; Teziç, Anayasa, s. 161. Ayrıca kuvvetler ayrılığı 1791, 1795 ve 1848 tarihli Fransız Anayasalarında da kabul edilmiştir. Bkz. Teziç, Anayasa, s. 494; Ergun Özbudun, Anayasalcılık ve Demokrasi, 1. bs., İstanbul Bilgi Üniversitesi Yayınları, İstanbul 2015, s. 18-19; Erdoğan, Anayasal Demokrasi, s. 216.

${ }^{71}$ Montesquieu, Kanunların Ruhu Üzerine (Çev. Şevki Özbilen), Seçkin Yayıncılık, İstanbul 2014, s. 174-183; Anayurt, Anayasa Hukuku, s. 349. 
Sartori'nin de belirttiği gibi anayasacılık açısından önemli olan anayasanın tek başına varlığı değildir ${ }^{72}$. Ası1 önemli olan anayasanın amacıdır. Anayasanın gerçek bir anayasa olabilmesi, hürriyetlerin korunması ve iktidarın sınırlandırılması amacına sahip olmasına bağlıdır ${ }^{73}$. Örneğin, Amerikan ve İngiliz anayasal belgeleri ile genel olarak Batı devletlerinin anayasaları bu amaca hizmet etmektedir ${ }^{74}$. Ancak bu amaca riayet edilmediği ve anayasaların da istismar edildiği durumlar vardır. Söz konusu yozlaşmayla anayasaların temel amacı ortadan kaldırılmaktadır ${ }^{75}$. Bu tür, yani iktidarı sınırlandırma amacı olmayan anayasalar ise gerçek anayasalar olamaz. Sartori'nin benimsediği gibi şekli anlamda bir anayasanın varlığı, gerçek anlamda anayasacılığa uygun bir düzenin olduğunu gösterme $z^{76}$. Burada yine "anayasa" isimli hukuk metinleri vardır. Ama bu anayasalar, olması gereken amaçların dışında başka amaçlarla çıkarılmışıtır ${ }^{77}$. Yazar, böyle anayasaları sözde anayasalar olarak isimlendirmektedir ${ }^{78}$. Örneğin, topluma belli bir ideolojinin benimsetilmesi, iktidarın kendini güvence altına almak istemesi ya da daha genel ifadeyle toplumun bir kalıba sokulması amaçlanıyor olabilir ${ }^{79}$. $\mathrm{Ne}$ var ki bu anlayış, anayasacılık düşüncesiyle bağdaşmaz. Çünkü anayasacılık, bireyin otonomisini ve hürriyetini korur $^{80}$.

72 Buna ilişkin bkz. Giovanni Sartori, "Constitutionalism: A Preliminary Discussion”, The Political Science Review, C. 56, S. 4, Y. 1962, s. 855; Özbudun, Anayasalc1lı, s. 5; Turhan, Anayasal Devlet, s. 67, 69; Turhan, "Anayasa ve Anayasacılık", s. 4.

73 Sartori, "Constitutionalism", s. 855; Özbudun, Anayasalc1lık, s. 5; Turhan, Anayasal Devlet, s. 67, 69; Turhan, "Anayasa ve Anayasacılık", s. 4.

74 Sartori, "Constitutionalism", s. 855; Turhan, Anayasal Devlet, s. 47; Özbudun, Anayasalcılık, s. 5. ABD Anayasası'nın iktidarı sınırlandırmasına ilişkin ayrıca bkz. Hayek, The Constitution, s. 182; Turhan, "Anayasa ve Anayasacıl1k", s. 4.

75 Sartori, "Constitutionalism", s. 855.

76 Sartori, "Constitutionalism", s. 861.

77 Sartori, "Constitutionalism", s. 861; Özbudun, Anayasalc1lı, s. 5.

${ }^{78}$ Sartori, "Constitutionalism", s. 858; Özbudun, Anayasalc1lı, s. 5. Bu tür anayasalara farkl isimler verilebilmektedir. Bunlardan birisi de anayasacılıksı anayasa kavramıdır. Anayasacılıksız anayasalar, birey hak ve hürriyetlerini koruma ve iktidarı sınırlandırma amaçları olmayan anayasalardır. Bu konu hakkında ayrıca bkz. Gözler, Teori I, s. 135; Gözler, Genel Esaslar, s. 72.

79 Bkz. Sartori, "Constitutionalism", s. 858. Hitler ve Stalin dönemi anayasaları tam da buna örnektir. Bkz. https://encyclopedia.ushmm.org/content/tr/article/third-reich-an-overview(E. 25.06.2020). Kubalı'ya göre, özellikle Birinci Dünya Savaşı'ndan sonra kabul edilen anayasaların çoğu ideolojik amaçlıdır. Bkz. Hüseyin Nail Kubalı, Anayasa Hukuku Genel Esaslar ve Siyasi Rejimler, Ersa Matbaacıl1k, İstanbul 1965, s. 136.

80 Zira anayasacılık, devletin siyasi tarafsızlığını da gerektirir. Devlet bireylerin kendi iyilerini tayin etmesine karışmaktan kaçınmalı ve olabildiğince fazla ve farklı düşünceyi korumalıdır. Buna ilişkin bkz. Arslan, Anayasa, s. 80-81. 


\section{B. Medine Vesikası ve Vesika'nın Bir Anayasa Olup Olmadığı Sorunsalı}

\section{Genel Olarak}

Anayasa kavramının anlaşılması, bir metnin anayasa olup olmadığının tespiti açısından büyük önem ifade etmektedir. Bununla beraber bir belgenin anayasa olup olmadığını tespit ederken hangi hususlara dikkat etmek gerekir, bunun da bilinmesi gerekir. O belgenin hazırlandığ 1 tarihi şartlar, içeriği, şekli ve hazırlandığı dönemde kendisine yüklenen anlam, belgenin niteliği üzerinde etkilidir. Tüm bunları belirlemek her zaman kolay değildir. Ancak konunun, birey hürriyetlerinin korunabilmesi maksadiyla dikkatle incelenmesi ve objektif olarak değerlendirilmesi gerekmektedir.

Medine Vesikası'nın niteliğinin tespit edilebilmesi bakımından, Vesika'nın hazırlandığı zamana, şartlara ve imzalanmasından sonraki döneme kısaca bakmak gerekir. İlk olarak Vesika'nın temelini oluşturan biatlar, Vesika'nın imzalandığı dönemde Medine'nin içerisinde bulunduğu sosyal ve siyasi şartlar incelenmeli; Vesika'nın hangi amaçla imzalandığı tespit edilmelidir.

\section{Medine Vesikası'nın İmzalandığı̆ Dönemde Siyasi ve Sosyal Koşullar}

\section{a) Vesika'nın Temeli Olarak Akabe Biatlart}

Hz. Peygamber'in doğduğu ve büyüdüğü Mekke, bir tür şehir devleti şeklinde yönetilmiştir. Şehrin yönetimi, Nedve ve Meşura adları verilen iki meclis tarafından sağlanmış ve devletin idari işleri aileler arasında paylaştırılmıştır. Her aile kendi yetki alanında emretme gücüne sahip olduğundan devlet yönetiminde bir ailenin diğerine üstünlüğü kabul edilmemiştir $^{81}$. Hz. Peygamber de bir devlet teşkilatının mevcut olduğu şartlarda tebliğ vazifesine başlamıştır.

Ancak Mekkeli müşrikler, bu tebliğ faaliyetlerine müsaade etmemiş ve Müslümanları çeşitli zulümlere maruz bırakmıştır ${ }^{82}$. Bu şartlar altında $\mathrm{Hz}$. Peygamber yeni bir yurt bulabilmek amacıyla hac vazifesi için Mekke'ye gelen kabilelerle görüşmeye başlamış, ziyaret ettiği on beş kabilenin

81 Muhammed Hamidullah, İslam Anayasa Hukuku, Beyan Yayınları, İstanbul 2018, s. 97.

82 Başta Hz. Peygamber olmak üzere, tüm Müslümanlara zulmedilmiş ve yollarından çevrilmeye çalışılmıştır. Örneğin, Hz. Peygamber'in namaz kıldığı sırada üzerine koyunun döl yatağ 1 atılmıştır. Bkz. İbn Hişam, İslam Tarihi (Çev. Hasan Ege), C. II, Kahraman Yayınları, İstanbul 2006, s. 71. 
hiçbirisinden olumlu yanıt alamamıştır ${ }^{83}$. Uğradığı on altıncı durak ise Medine'den gelen küçük bir grup olmuştur ${ }^{84}$.

Altı kişilik bu grupla yapılan görüşmeler, birinci akabe biatı olarak tarihe geçmiş ve bu kişilerin İslam'a girmesiyle sonuçlanmıştır ${ }^{85}$. Birinci biatta bulunan grup, ertesi y1l on iki kişi halinde, bu sefer ailelerini de temsilen toplantıya katılmıș ve Hz. Peygamber'e ne pahasına olursa olsun itaat edeceklerini açıkça ifade etmişlerdir ${ }^{86}$. Üçüncü akabe biatı olarak bilinen biat ise, son biattan bir yıl sonra, yine hac mevsiminde gerçekleşmiştir. Bu biatta, yetmiş bir erkek ve iki kadınla biata katılan Medineliler, Hz. Peygamberi aralarına katılmak ve Medine'de yaşamak üzere davet ederek, O'nu koruyacaklarına dair söz vermişlerdir ${ }^{87}$.

Son biatta, her kabileyi temsilen kabile mensupları tarafindan "Nakib"ler ve bu nakiblerin de lideri olacak şekilde Hz. Peygamber tarafindan "Nakib ünNukaba" seçilmiştir ${ }^{88}$. Bu nakiblerin seçilmesi, Hz. Peygamberin dini tebliğ vazifesinin yanı sıra kendisine biat edenler üzerinde siyaseten de söz sahibi olmas1 ve biat edenlerin kendi iradeleriyle bir lider olarak Hz. Peygamberi kabul etmeleri bakımından büyük önem ifade etmektedir. Neticede Medineliler, yeni oluşan topluluğun idaresinde Hz. Peygamberi tek yetkili

83 Muhammed Hamidullah, İslam Peygamberi (Çev. Salih Tuğ), C. I, Yeni Şafak, Ankara 2003, s. 149-150; Hamidullah, İslam Anayasa Hukuku, s. 100. Hz. Peygamber yeni bir vatan bulabilmek için Sakif ve Ben-i Kelb gibi çeşitli aile ve kabilere ziyarette bulunmuştur. Konuya iliş̧kin bkz. İbn Hişam, s. 75-76, 82.

${ }^{84}$ Hamidullah, İslam Peygamberi, s. 150; Hamidullah, İslam Anayasa Hukuku, s. 100.

85 Hamidullah, İslam Peygamberi, s. 150; Hamidullah, İslam Anayasa Hukuku, s. 100; Salih Tuğ, İslam Ülkelerinde Anayasa Hareketleri, İrfan Yayınevi, İstanbul 1969, s. 27. Birinci biatın içeriği ve Türkçe çevirisi için bkz. İbn Hişam, s. 93. İbn Hişamın aksine Hizmetli, Birinci Akabe biatinde yalnızca görüşme olduğunu ve biat (ahitleşme) olmadığını iddia eder. Ayrıca yazar biatları toplamda iki sefer olmuş şekilde ele alır. Bkz. Hizmetli, s.138-139. Birinci Akabe Biatına katılanlar ve konuya ilişkin ayrıca bkz. İbn Hişam, s. 87-90.

86 Hamidullah, İslam Peygamberi, s. 153-154; Hamidullah, İslam Anayasa Hukuku, s. 100; Tuğ, s. 27-28; Bkz. İbn Hişam, s. 99; Mevlüt Koyuncu, "Medine Devleti", Sakarya Üniversitesi Fen Edebiyat Dergisi, C. 11, S. 2, Y. 2009, s. 90. Biat metninin Türkçe çevirisi için bkz. Hamidullah, İslam Peygamberi, s. 154. İkinci Akabe biatına katılan Medineliler için bkz. İbn Hișam, s. 91-93.

87 Konuya ilişkin bkz. Hamidullah, İslam Peygamberi, s. 157-158; Hamidullah, İslam Anayasa Hukuku, s. 100-101; Tuğ, s. 27-28; Koyuncu, s. 90-91; Hz. Ali/Ebu Yusuf/Abdülkerim Zeydan, İslam'da Ferd ve Devlet Münasebetleri, 2. Bs., Kayıhan Yayınevi, İstanbul 1995, s. 74; İbn Hişam, s. 103.

88 Hamidullah, İslam Peygamberi, s. 158-159; Hamidullah, İslam Anayasa Hukuku, s. 101; Koyuncu, 90-91. Nakiblerin isimleri ve nakiblerin isimlerinin açıkça yer aldığı Kab bin Malik'in şiiri için ayrıca bkz. İbn Hişam, s. 104-107. 
olarak görmüş, bu teslimiyetin gereğini yerine getirmeyi ve Hz. Peygamberi korumayı kabul etmişlerdir ${ }^{89}$.

Hamidullah bu biatları (kanaatimizce Medine Vesikası'nın da bu kapsama dahil edilmesi gerekir) bir toplum sözleşmesi olarak görür. Zira Locke, Hobbes ve Rousseau gibi Batılı bazı düşünürler, devletin ilk oluşumunu varsayımsal bir toplum sözleşmesine, yani bireylerin yetkilerini sözleşme yaparak bir iktidara devretmesine dayandırmışlardır ${ }^{90}$. Hamidullah, bu yazarların bahsettiği toplum sözleşmelerinin, varsayıma dayandığını; ancak Hz. Peygamber'e biat edilmesini ve hicretten sonra sosyal ve siyasi konularda insanların O'nu tek yetkili olarak tanımalarının, gerçek bir toplum sözleşmesi olduğunu kabul eder ${ }^{91}$.

\section{b) Hicretin Gerçekleştiği Strada Medine'nin Sosyal ve Siyasi Durumu}

Miladi 622 y1lında Hz. Peygamber, Medinelilerin daveti üzerine Medine'ye hicret etmiştir ${ }^{92}$. Hz. Peygamber Medine'ye vardığında Medine'de bir devlet yoktur. Bu sırada Arap Kabileleri ve Yahudiler dağınık halde ve sürekli bir çatışma ve kaos ortamında yaşamlarını sürdürmektedirler ${ }^{93}$. O dönemde Medine'de kabileler ve Yahudiler gerek kendi içlerinde gerek birbirleriyle bir çatışma içerisinde olduklarından, kabul ettikleri ortak bir lider ya da hukuk düzeni de mevcut değildir ${ }^{94}$.

Hz. Peygamber, İslam'ın gereğince tebliğ edilip yaşanabilmesi için düzenli bir sosyal ve siyasi hayatın gerektiğini fark etmiştir. Medine'ye hicret eden Müslümanların Mekke müşriklerinin saldırısına açık olmaları nedeniyle ve İslam'ın yayılmasının hızlanması için barış ve emniyetli bir ortamın gerekliliği kaçınılmazdı9 ${ }^{95}$. $\mathrm{Bu}$ nedenle merkezi bir teşkilat kurma girişimlerinde bulunulmuş; Medine'de merkezî bir siyasi iktidar veya oluşum söz konusu olmadığından siyasi çekişme ile karşılaşılmadan, Hz. Peygamber teşkilatlanmak için gerekli hazırlıkları daha rahat yapabilmiştir ${ }^{96}$.

89 Bkz. Zeydan vd., s. 74-75.

90 Bkz. Hamidullah, İslam Anayasa Hukuku, s. 99.

91 Bkz. Hamidullah, İslam Anayasa Hukuku, s. 99.

92 Hicret yolculuğuna ve Medine'ye ulaşmasına ilişkin ayrıca bkz. İbn Hişam, s. 151-165. Konuya ilişkin ayrıca bkz. Hizmetli, s. 139.

93 Bkz. Hamidullah, İslam Peygamberi, s. 186. Kabileler arasındaki çekişme öyle bir haldedir ki, hicretten sonra bile Evsli birisi Hazreçli birisinin imam olması halinde namazda cemaate dahil olmamıştır. Bkz. Hamidullah, İslam Anayasa Hukuku, s. 21.

94 Mustafa Özkan, Medine Vesikası/Anayasası ve Birlikte Yaşam, Fecr Yayınları, Ankara 2018, s. 55.

95 Konuya ilişkin bkz. Özkan, s. 56-58

96 Bkz. Hamidullah İslam Peygamberi, s. 188-189. Zira doğrudan bir kabilenin üyesi olmayan Hz. Peygamber, kabileler açısından devlet başkanı olmaya en uygun kişidir. Zira Hz. 
Siyasi oluşumun, diğer ifadeyle devlet organizasyonunun sağlanabilmesi için birçok adım atılmıștır. Hicret yılında nüfus sayımı yapılmış, Müslüman olsun olmasın Medine'de kaç kişinin yaşadığ 1 tespit edilmiştir ${ }^{97}$. Bunun yanı sıra mallarını ve yurtlarını geride bırakıp gelen muhacirlerin Medine'de sosyal, ekonomik ve siyasi hayata uyum sağlayabilmeleri için "hususi din kardeşliği" veya "muahat" tesis edilmiş; muhacir ve ensar arasında soy bağıyla gelen kardeşlikten daha sıkı bir kardeşlik ve irtibat sağlanmıştır ${ }^{98}$.

Ayrıca benzer zamanlarda yapılan ilk faaliyetler arasında Medine'nin sınırlarının belirlenmesi yer alır. Zira sınırları belirsiz bir devlet düşünmek mümkün değildir. Hz. Peygamber, sınırın tespit edilmesi konusunda Kâ'b bin Mâlik'i görevlendirmiștir. Kâ'b bin Mâlik, Medine'yi merkez alarak 12 millik bir daire çizmiş ve yeni kurulacak olan devletin sınırlarını belirlemiştir ${ }^{99}$.

Hz. Peygamber'in tüm faaliyetlerinin bir devlet kurma amacina hizmet ettiği söylenebilir. Devletin insan unsurunun tespiti, toprak unsuru olan vatanın sinırlarının belirgin hale getirilmesi, muhacir ve ensar arasında manevi irtibatın kuvvetlendirilmesi ve Medine'de yer alan gayrimüslim unsurların da siyasi bir bağ ile bu oluşuma dahil edilmesi, bunu gösterir niteliktedir ${ }^{100}$.

Peygamberin lider olması herhangi bir kabilenin diğeri üzerinde üstünlük veya otorite sağlaması anlamına gelmemektedir. Konuya ilişkin bkz. Hamidullah, İslam Anayasa Hukuku, s. 26.

97 Bkz. Hamidullah, İslam Anayasa Hukuku, s. 103; Muhammed Hamidullah, Hemmam İbn Munebbih'in Sahifesi (Çev. Talat Koçyiğit), Ankara Üniversitesi Basımevi, Ankara 1967, s. 27; Tayyib Okiç, "İslamiyette İlk Nüfus Sayımı", Ankara Üniversitesi Illahiyat Fakültesi Dergisi, C. 7, S. 1, Y. 1958, s. 12-15; Abdurrahman Demirci, "Medine Vesikası: Olușum Süreci ve Zimmet Antlaşmalarına Etkisi”, İstem, S. 19, Y. 2012, s. 259. Hamidullah'ın belirttiğine göre, nüfus sayımında Müslüman nüfus toplamda 1500 ve bazı kaynaklara Hristiyan nüfus 50 iken, toplam nüfus ise 10000 civarındadır. Bkz. Hamidullah, İslam Anayasa Hukuku, s. 21, 24; Ahmet, Güneş, "Medine Vesikası'nın İslam Hukuku Açısından Kaynak Değeri”, EKEV Akademi Dergisi, S. 34, Y. 2008 (Kış), s. 213.

98 Hizmetli, s. 146 Mustafa Safa, "Hicret Sonrasında Medine'de Sosyal ve Dini Hayat", Toplum Bilimleri Dergisi, C. 9, S. 17, s. 364-365; İsmail Hakkı Atçeken, "İslam Tarihinde Birarada Yaşama Tecrübesi (Asr-1 Saadet ve Endülüs Örneği)”, ISAM, S. 14, Y. 2007, s. 48. Bu hususi kardeşlik, Hz. Peygamber'in "Allah için ikişer ikişer kardeş olun" demesiyle vukuu bulmuştur. Bkz. İbn Hişam, s. 176; Safa, s. 364. Ayrıca bu kardeşlik Kur'an-1 Kerim'in Haşr Suresi'nin 9. ayetinde şu şekilde açılanmaktadır: "Daha önceden Medine'yi yurt edinmiş ve gönüllerine imanı yerleştirmiş olan kimseler, kendilerine göç edip gelenleri severler. Onlara verilenlerden dolayı içlerinde bir rahatsızlık hissetmezler. Kendileri zaruret halinde bulunsalar bile onlarl kendilerine tercih ederler. Kim nefsinin cimriliğinden korunursa, işte onlar kurtuluşa erenlerdir.” Hz. Peygamber'in kardeş olarak belirlediği kişiler için ayrıca bkz. İbn Hişam, s. 176-177.

99 Bkz. Koyuncu, s. 94. Konuya ilişkin açıklamalar için ayrıca bkz. Hamidullah, Hemmam İbn Munebbih'in Sahifesi, s. 27.

${ }^{100}$ Medine Şehir Devleti'nin devletin oluşumu için gerekli tüm unsurlara sahip olduğu dair inceleme için ayrıca bkz. Fethi Osman, Düşünce Devleti, Fecr Yayınları, Ankara 1992, s. 17-20. 


\section{Medine Vesikası'nın İmzalanması}

Medine Vesikası, hicretin ilk yılında Medine'de yaşayan Arap kabileleri ve Yahudiler arasında imzalanmıştır ${ }^{101}$. Vesikanın iki anlaşma metninden, yani Müslümanların kendi aralarında imzaladığı ve Yahudilerle imzalanan anlaşmaların bütününden (birleşiminden) oluştuğuna dair iddialar vardır ${ }^{102}$. Ayrıca hicretin ilk yılı imzalandığı genel olarak kabul ediliyor olsa da Bedir Savaşı'ndan önce veya sonra imzalandığına dair farklı rivayetler ve görüssler de mevcuttur ${ }^{103}$.

Vesika, Wellhausen tarafından maddeleştirilmiş ve günümüze bu şekliyle nakledilmiştiir ${ }^{104}$. Yazar, metni 47 madde haline getirmiştir ${ }^{105}$. Hamidullah ise yazarın bazı maddeleri tek maddede birleştirdiğini belirterek, kendisi madde sayısını 52 olarak tespit etmiştir ${ }^{106}$. Tüm ihtilaflara rağmen değişmeyen husus, (Wellhausen'ın sistematiği esas alınmıştır) 1-23. maddelerin Müslümanlara ilişkin; 24-47. maddelerin ise Yahudilere ilişkin olmasidır ${ }^{107}$.

${ }^{101}$ Vesikanın imzalanmasıyla Arap kabileleri ile Yahudilerin hak ve yükümlülüklerinin karşı1ıklı olarak belirlenmesi ve güvence altına alınması sağlanmıştır. Bkz. Anver Emon, "Reflections on The "Constitution of Madina" an Essay on Methodology and Ideology in Islamic Legal History”, Journal of Islamic and Near Eastern Law, S. 103, Y. 2001, s. 103, 105.

${ }^{102}$ Bkz. Hamidullah, İslam Peygamberi, s. 190; Özkan, s. 41-42; Ayrıca Vesika'nın varlı̆̆ına ilişkin şüphelerini dile getiren yazarlar da vardır. Zira Vesika'nın aslına veya arkeolojik olarak kalıntılarına ulaşılamamıştır. Ayrıca Vesika'dan bahseden kaynakların Hz. Peygamber'in vefatından 200 yıl sonra kaleme alınmış olması da bu iddiaları destekler niteliktedir. Bkz. Emon, s. 103, 107. Konuya ilişkin kapsamlı bir inceleme için bkz. Emon, s. $115-120$.

${ }^{103}$ Bkz. Özkan, s. 41-42; Demirci, s. 260; Safa, s. 367. Bu tür tartışmalar Yahudilerin Vesika’ya neden taraf olduğunun tespitinde önem arz eder. Zira Bedir Savaşından önce olması, güçlü bir haldeyken Vesika'ya taraf olmalarını gösterir. Savaştan sonra taraf olmaları ise Müslümanların güçleri karşısında korktukları ve bu nedenle Vesika'ya taraf oldukları düşüncesine neden olur. Konu hakkında bkz. Özkan, s. 60-66; Demirci, s. 260-261.

${ }^{104}$ Hamidullah, İslam Peygamberi, s. 190; Hamidullah, İslam Anayasa Hukuku, s. 103; Tuğ, s. 40; Güneş, s. 213; Emon, s. 107 (dipnot 15).

${ }^{105}$ Hamidullah, İslam Peygamberi, s. 190; Hamidullah, İslam Anayasa Hukuku, s. 103; Tuğ, s. 40; Güneş, s. 213.

${ }^{106}$ Bkz. Hamidullah, İslam Peygamberi, s. 190-191; Koyuncu, s. 96; Özkan, s. 44-45. Vesikanın maddeleştirilmiş tam metni için bkz. Hamidullah, İslam Anayasa Hukuku, s. 103110; Hamidullah, İslam Peygamberi, s. 202-210; Özkan, s. 24-35. Vesika'nın maddeleştirilmemiş hali için ayrıca bkz. İbn Hişam, s. 172-175.

${ }^{107}$ Bkz. Hamidullah, İslam Anayasa Hukuku, s. 111-112; Tuğ, s. 40; Özkan, s. 44-45; Safa, s. 367. 
Yahudiler ve Müslümanlar (Arap Kabileleri), Hz. Peygamber liderliğinde bir araya gelmiş ve Yahudiler Müslümanların oluşturduğu kardeşliğin karşısında durmak yerine siyasi dengeler gereğince Vesika'ya taraf olmayı kabul etmişlerdir ${ }^{108}$. Arap kabileleri ve Yahudiler, Enes b. Malik'in evinde toplanmışlardır. Aynı şehirde ortak yaşamın nasıl tesis edilebileceğine ilişkin olarak; adli, askeri, siyasi, sosyal ve ekonomik konularda istişarelerde bulunulmuştur ${ }^{109}$. Nihayet, Vesika imzalanmış ve bir organizasyon tesis edilmesi, Hz. Peygamberin adli-idari konularda nihai hüküm verme ve yürütme makamı olarak kabul edilmesi gibi önemli kararlar alınmıştır ${ }^{110}$.

Öyleyse Vesika, bir tür kuruluş belgesi olarak kabul edilebilir. Devletsiz ve merkezi otoriteden yoksun bir yerleşim yerinde, farklı inanç ve irktan insanlar bir araya gelmiş; ortak yaşamın sağlanabilmesi amacıyla yazılı bir metni kabul etmişlerdir. Hamidullah'ın da belirttiği gibi gerek Akabe biatları gerek Medine Vesikası bu yönleriyle toplumsal uzlaşı metinleridir. Diğer bir ifadeyle somut sosyal sözleşmelerdir ${ }^{111}$.

\section{Medine Vesikası’nın “Anayasa” Olarak İncelenmesi \\ a) Genel Olarak Medine Vesikası'nın Getirdikleri}

Medine Vesikası'nın 1. ve 23. maddeleri arasındaki hükümleri Müslümanlara ilişkindir. $\mathrm{Bu}$ maddelerde sözleşmenin tarafları (md. 1); oluşturulan kardeşliğin (siyasi bağın) ismi, "ümmet" olmaları (md. 2); kabilelere ilişkin ceza hukuku ve Müslümanların ilişkileri (md. 3-15); Vesika'ya taraf olan Yahudilere adaletle muamelede bulunulacağ 1 (md. 16); diğer askeri ve adli konular (md. 17-22) ve her türlü uyuşmazlığın nihai çözüm mercinin Allah ve Resul'u olduğu düzenlenmiştir ${ }^{12}$.

Vesika'nın 24. ve 47. maddeleri arasındaki hükümleri ise Yahudilere ilişkindir. Bu maddelerde, Yahudilerin hukuki statüsü, hakları, savaşlardaki durumları ve Mekkeli müşriklerle ilişkileri (md. 24-38, 40-41, 43-45); Medine

${ }^{108}$ Benzer yönde bkz. Hizmetli, s. 148; Hamidullah, Hemmam İbn Munebbih'in Sahifesi, s. 26; Servet Armağan, "İlk Yazılı Anayasa: Medine Vesikası", 2016-2017 Siyer Mektebi Müfredatt-Iman Şehri Medine (7. Ders), s. 107, http://www.siyervakfi.org/ilk-yazilianayasa-medine-vesikasi-prof-dr-servet-armagan/(E. 25.06.2020); Güneş, s. 213; Emon, s. 105.

${ }^{109}$ Bkz. Koyuncu, s. 95; Armağan, s. 107; Güneş, s. 213.

${ }^{110}$ Bkz. Koyuncu, s. 95; Emon, s. 105; Benzer yönde bkz. Güneş, s. 213.

${ }^{111}$ Konuya ilişkin bkz. Hamidullah, İslam Anayasa Hukuku, s. 99.

${ }^{112}$ Maddeler için bkz. Hamidullah, İslam Anayasa Hukuku, s. 103-107; Hamidullah, İslam Peygamberi, s. 206-208; Özkan, s. 25-31. 
vatanında herkesin güven ve huzur içerisinde olduğu, yani vatan topraklarının haram beldesi olmasi (md. 39); Allah ve Hz. Peygamber'in bazı uyuşmazlıklarda nihai karar merci olmas ${ }^{113}$ (md. 42); kurallara herkesin riayet etmesi gerektiği, kuralların herkese eşit bir şekilde uygulanacağ 1 ve sözleşme taraflarının kurallara riayet ettiği müddetçe istisnasız korunacağı (md. 46-47) düzenlenmiştir ${ }^{114}$.

\section{b) Medine Vesikası'nın Anayasalar Bağlamında Değerlendirilmesi ve Anayasa Olup Olmadiğ Sorunsalı}

Vesika, Miladi 7. yüzyılda imzalanmış bir belgedir. Ancak anayasaların ilk toplumlardan beri mevcut olduğunu benimseyen yazarlar, Vesika'dan bir anayasa olarak bahsedilebileceğini iddia etmektedirler. Biz burada söz konusu iddiaların haklı olabileceğinin ve ilk toplumlarda da anayasaların olduğunun kabul edilmesi halinde Vesika'nın bir anayasa olup olmadığını, anayasaların temel unsurları ve özellikleri çerçevesinde değerlendireceğiz. Nihayetinde belgenin niteliğini bu kapsamda tespit etmeyi amaçlamaktayız.

Bu konuda Hamidullah ve Tuğ gibi yazarlar başta olmak üzere birçok yazar, Vesika'yı anayasa olarak kabul etmektedir ${ }^{115}$. Örneğin Hamidullah çok ciddi bir iddia ileri sürmektedir. Yazar, Vesika'yı dünyanın, dolayısıyla insanlığın ilk yazılı anayasası olarak kabul etmektedir ${ }^{116}$. Benzer şekilde Tuğ, "...daha evvel rastlanmayan, evvelden beri hukuki kaidelere devlet iktidarın temsil edenleri boyun eğdirmeye müncer olacak tarzda "yazıll" şekilde tevsik edecek mahiyettedir" diyerek, Vesika'yı adeta anayasacılık ürünü olan

113 Özkan, rıza unsurunu ve kabile reislerinin tüm kabile adına toplantıya katılmalarını "temsili katılım” olarak nitelendirir. Bkz. Özkan, s. 47. Bu husus Vesika'nın 1. maddesinde şu şekilde ifade bulmuştur: "Bu kitap, Peygamber Muhammed tarafindan Kureyşli ve Yesribli müminler ve bunlara tâbi olanlarla sonradan onlara katılmış olanlar ve onlarla beraber cihad edenler için düzenlenmiştir."

${ }^{114}$ Maddeler için bkz. Hamidullah, İslam Anayasa Hukuku, s. 108-110; Hamidullah, İslam Peygamberi, s. 208-210; Özkan, s. 31-35. Vesika, eşitlikçi ve ümmet vurgusunun hâkim olduğu bir metindir. Ayrıca bkz. Demirci, s. 264; Özkan, s. 45.

115 İbn Hişam ise Vesika'yı "Resûlullah (Sallallahü Aleyhi ve Sellem)'in Muhâcirler ile Ensar Arasında Mektubu ve Yahûdilerle saldırmazlık Andlaşması" başlı̆ğ altında, yalnızca bir anlaşma olarak incelemektedir. Bkz. İbn Hişam, s. 172-176. Armağan da Tuğ ve Hamidullah'a benzer şekilde Vesika'yı anayasa hukuku ve siyaset bilimi bakımından "ilk" olarak değerlendirir. Bkz. Armağan, s. 106.

${ }^{116}$ Bkz. Hamidullah, İslam Anayasa Hukuku, s. 102-103; Güneş, s. 212. Hatta al-Hibri, Amerika Birleşik Devletleri'nin kurucu babalarının anayasayı yaptıkları sırada "Vesika"dan ve İslam dininden esinlenmiş olabileceklerini dahi iddia etmektedir. Bkz. Azizah al-Hibri, "Islamic and American Constitutional Law: Borrowing Possibilitiesor a History of Borrowing?", Islamic and American Constitutional Law, C. 1, S. 2, Y. 1999, s. 499-514, 511 (dipnot 126); Benzer yönde bkz. Emon, s. 124. 
anayasalara benzer niteliklere sahip olarak görmektedir ${ }^{117}$. Bu iddiaların ciddiliği karşısında daha temkinli olmakta ve konunun objektif bir gözle ele alınmasında yarar vardır.

Öncelikle geniş ve dar anlamda anayasa tanımları doğrultusunda Vesika'da devlet organlarının, yetkilerin, hak ve hürriyetlerin varlı̆̆ının tespit edilmesi gerekmektedir. İlk olarak, açık bir şekilde devletin organları belirtilmemiş olsa da Vesika'nın 23. maddesinde "Üzerinde ihtilâfa düşülen konular Allah'a ve Resulü Muhammed'e arz edilecektir.”; 42. maddesinde "Bu yazıda adı geçen kimseler arasında meydana gelmesinden endişe edilen anlaşmazlık ve öldürme vakalarının Allah'a ve Resulü Muhammed'e arz edilmesi gerekir..." ; 47. maddesinde ise, “...iyilik yapanlar ve sorumluluğunun bilincinde olanlar Allah ve Resulü'nün himayesi altındadır." denilmek suretiyle devlet teşkilatı içerisinde yargı organına işaret edilmektedir. Ayrıca 36/a maddesindeki "Yahudilerden hiçbir kimse Hz. Muhammed'in izni olmadan -Müslümanlarla birlikte savaşakatılamayacaktır." ifadesi, önemli konularda Hz. Peygamberin sevk ve idare yetkisi olduğunu gösterir niteliktedir. Özellikle 23 . ve 42 . maddeler ${ }^{118}$ açısından konuya bakıldığında, adaletin tesis edilmesi merkezi bir makama verilmiştir. Bahsi geçen konuların çözüme kavuşturulmasında tek yetkili $\mathrm{Hz}$. Peygamberdir ${ }^{119}$.

Ancak yasama, yani kanun koyma açısından durum daha farklıdır ve yasama organı Vesika'da yer bulamamıştır. Zira İslam hukukunda temel iki kaynak Kur'an ve sünnet olduğundan ${ }^{120}$; kural koymaya ilişkin hükümlerin Vesika'da yer bulamaması şaşılacak bir durum değildir. Bu konuda Hamidullah, yasama kuvvetinin devlet başkanına ait olmadığını, ancak Allah ve Hz. Peygamber'e, peygamberlik sifatı nedeniyle ait olduğunu belirtir ${ }^{121}$.

\footnotetext{
${ }^{117}$ Bkz. Tuğ, s. 46.

${ }^{118} \mathrm{Bu}$ maddelerde Hz. Peygamber ve Kur'an (vahy), uyuşmazlığın çözümünde tek kaynak olarak gösterilmektedir. Bkz. Tuğ, s. 46.

${ }^{119}$ Armağan, s. 110.

120 İslam hukukunda kural koyan olarak "Şari” ifadesi kullanılır. "Şari' sözü İslam kanununu koyan ma'nasına Cenab-l Hak ve onun tarafindan tebliğe memur bulunması hasebiyle resûlüdür, ya'ni Hazreti Muhammed de şari'dir.” Bkz. Sabri Şakir Ansay, Hukuk Tarihinde İslam Hukuku, 2. Bs., Ankara Üniversitesi İlahiyat Fakültesi Yayınları, Ankara 1954, s. 15. Kur'an ve sünnet asli iki kaynaklardır. Bu naslardan hüküm çıkarmak, elbette akıl vasıtasıyla mümkündür. Bununla birlikte devlet başkanının yanı sıra yargı organlarının da içtihat ve diğer bazı yollarla hüküm çıkarmaları mümkündür. Daha fazla bilgi ve değerlendirme için bkz. Muammer Vural, "Yasama Kavramı ve Yetkisi Açısından Pozitif Hukuk ile İslâm Hukuku Arasında Bir Mukayese", Atatürk Üniversitesi İlahiyat Fakültesi Dergisi, S. 36, Y. 2011, s. 189-194.

${ }^{121}$ Bkz. Hamidullah, İslam Anayasa Hukuku, s. 25.
} 
Diğer konu ise, Vesika'da bireylerin hak ve yükümlülüklerinin yer alıp almamasıdır. Vesika'nın farklı maddelerinde gerek Yahudilerin gerek Müslümanların hak ve yükümlülükleri geniş ölçüde yer bulmuştur ${ }^{122}$. Bunlardan kısaca bahsetmek gerekirse; Vesika'nın 37/b maddesi, "Hiçbir kimse müttefiklerine karşı suç işleyemez; mazluma muhakkak yardım edilecektir." şeklindedir. Buna göre toplumsal hayat içerisinde herkesin diğer kişilerin hakkına riayet etmesi gerektiği ve zulme uğrayanların da zararının karş1lanacağ 1 belirtilmektedir. Vesika'nın 25/a maddesinde ise, "Ben-i Avf Yahudileri müminlerle birlikte bir ümmet teşkil eder. Yahudilerin dinleri kendilerine, müminlerin dinleri de kendilerinedir. Buna mevlâları da dahildir ${ }^{123}$." denilmek suretiyle, herkesin ayrım olmaksızın din ve vicdan hürriyetine sahip olduğu belirtilmektedir ${ }^{124}$. Bu çerçevede bir yönüyle vatandaşlık tanımlanmış ve vatandaşların ülke sınırları dahilinde huzur içerisinde yaşaması ve emniyetin devlet eliyle sağlanmas ${ }^{125}$, Vesika'da açıkça güvence altına alınmıştır.

Burada yapılan içeriğe yönelik incelemelere ilave olarak Vesika'nın anayasacılık unsurları bakımından değerlendirilmesi gerekir. Nitekim anayasalar, doğrudan iktidarı sınırlandırma amacına sahip olması gereken metinlerdir. $\mathrm{Bu}$ bakımdan anayasalarda, kuvvetler ayrilığ 1 ve hukukun üstünlüğü, yani iktidarın sınırlandırılması tesis edilmeli ve hürriyetler için güvence sağlanmış olmalıdır. Aynı zamanda devlet organlarının denetlenmesi de hukukun üstünlüğünün gereklerindendir. Medine Vesikası'na bu pencereden bakılarak değerlendirilme yapılmalıdır. İlk olarak Vesika'da

122 Örneğin, mali konulara ve savaș haline ilişkin hak ve yükümlülükler, madde 3, 12, 17, 23, 24 vd. gibi farklı maddelerde açıklığa kavuşturulmuş, yani hukuki düzenlemeye konu edilmiştir. Bkz. Tuğ, s. 46. Konuya ilişkin ayrıca bkz. Armağan, s. 108.

${ }^{123}$ Diğer Yahudi kabilelerin de aynı hak ve hürriyetlere sahip oldukları açıkça belirtilmektedir. Buna ilişkin bkz. Vesika, madde $25 \mathrm{vd}$. Bu durum anayasal vatandaşlığa benzer. Zira anayasal vatandaşlık, toplumu oluşturan fertler arasındaki farklılıklara bakılmaksızın, diğer bir ifadeyle din, dil, ırk veya düşünce ayrımı olmaksızın, toplumu oluşturan herkesin eşit şekilde varlığının korunmasını ve devlet idaresinin herkese eşit muamelesini gerektirir. Bkz. Fazıl Hüsnü Erdem, “Anayasal Vatandaşlık ve Yeni Anayasa”, Liberal Düşünce, S. 66, Y. 2012, s. 52.

${ }^{124}$ Bkz. Armağan, s. 112; Güneş, s. 215. Yahudilerin tek bir ümmet içerisinde kabul edilmesi ve din ve vicdan hürriyetine sahip olmaları nedeniyle, Vesika, Yahudilerin ne dinlerine ne de dünya hayatlarına katlanılamaz bir yük getirmiştir. Aksine Vesika'nın sağladığı vatandaşlık, Yahudiler için daha emniyetli bir ortam sağlamıştır. Benzer yönde bkz. Hamidullah, İslam Anayasa Hukuku, s. 25-27.

${ }^{125}$ Bkz. Vesika, madde 39'da Medine Haram beldesi, yani Vesika'da taraf olanların daha önce belirlenen Medine sınırları içerisinde emniyette olduğu/olacağı açıkça belirtilmiştir. Ayrıca bkz. Gayrimüslimlerin canlarının da Müslümanların canları gibi değerli olduğuna dair bkz. Güneş, s. 214. 
kuvvetler ayrılığına yer verilip verilmediğinin tespit edilmesi gerekir. Vesika'nın 36/a maddesine göre, önemli meselelerde Hz. Peygamberin sevk ve idare yetkisinin olduğu; 23 ve 42 . maddeler $^{126}$ açısından konuya bakıldığında ise, adaletin tesis edilmesinin merkezi bir makama, yani yalnızca Hz. Peygamber'e verildiği görülmektedir ${ }^{127}$. Ayrıca Vesika'nın kurduğu hukuk düzeni ve İslam hukuku bağlamında yasama kuvvetine bakıldığında ise yasama kuvvetinin devlet başkanına değil, ancak Allah ve Hz. Peygamber'e ait olduğu görülür ${ }^{128}$. Dolayısıyla Vesika kuvvetlerin ayrılması gibi bir prensibi konu almamaktadır ${ }^{129}$.

Vesika'nın değerlendirilmesine ilişkin diğer konu ise hukukun üstünlüğü konusudur. Hukukun üstünlüğü, kişinin keyfi yönetiminin karşıtı olarak, hukukun yönetimini gerektirir ${ }^{130}$. Bu bağlamda hukukun üstünlüğ̈̈, hukuk kurallarının tek taraflı bir iradeyle öngörülemez bir şekilde değiştirilmesini ve hukuk kurallarının uygulanmasından imtina edilmesini önlemek şeklinde anlaşılmalıdır ${ }^{131}$. Dolayısıyla kabul edilen hukuk kurallarının, kuralı koyanlar için de bağlayıcı olduğu ve siyasi iktidarın bazı ilke ve kurallarla sınırlı olduğu kabul edilmiştir ${ }^{132}$.

Vesika'nın 13. maddesinde ${ }^{133}$, kuralların herkes için bağlayıcı olduğu ve hiçbir farklı uygulama olmadan herkese eşit olarak uygulanacağı hüküm altına

12623 ve 42. maddelerde, Hz. Peygamber ve Kur'an, uyuşmazlığın çözümünde tek kaynak olarak gösterilmektedir. Bkz. Tuğ, s. 46.

${ }^{127}$ Bkz. Koyuncu, s. 98.

${ }^{128}$ Bkz. Hamidullah, İslam Anayasa Hukuku, s. 25. Elbette devlet başkanının idari konularda emretme veya kural koyma yetkisi vardır. Bkz. Hamidullah, İslam Anayasa Hukuku, s. 25. Ayrıca İslam hukukunda içtihat, icma yollarıyla herkesin uyması gereken kurallar tespit edilebilir. Ancak bunlar Kur'andan çıkarılan hükümlerdir ve Kur'an'a aykırı olamazlar. Benzer yönde bkz. Vural, s. 89-94.

${ }^{129}$ Zira kuvvetler ayrılığının teorik temelleri Locke ve Montesquieu tarafından atılmıştır. Montesquieu, bu teorisini, Kanunların Ruhu Üzerine isimli eserinin "İngiliz Anayasası Üzerine" başlığı altında 18. yüzyılda kaleme almıştır. İlgili bölüm için bkz. Montesquieu, s. $174-183$.

${ }^{130}$ Bkz. Eamonn Butler, Özgür Toplumun Temelleri (Çev. Hakan Şahin), 1. Bs., Liberte Yayınları, Ankara 2016, s. 136; Peter Rijpkema, "The Rule of Law Beyond Thick and Thin", Law and Philosophy, S. 32, Y. 2013, s. 795; Eren, Anayasa Hukuku, s. 207.

${ }^{131}$ Cengiz Gül, Iktidarın Sinırlandırılmast ve Hukuk Devleti, 1. Bs., Adalet Yayınevi, Ankara 2010, s. 173; Arslan, Anayasa, s. 67; Butler, s. 136; Erdoğan, Anayasal Demokrasi, s. 118.

${ }^{132}$ Yaşar Karayalçın, "Hukukun Üstünlüğü (Kavram-Bazı Problemler)", Hukuk Devleti (İçinde) (Haz. Hayrettin Ökçesiz), 1. Bs., AFA Yayınları, İstanbul 1998, s. 126; Gül, Hukuk Devleti, s. 173; Butler, s. 136; Erdoğan, Anayasal Demokrasi, s. 118, 137-150.

${ }^{133}$ Madde metni şu şekildedir: "Takvâ sahibi müminler saldırganlara, haksız bir fiil tasarlayanlara ve cürüm ișleyenlere, bir hakka tecavüz edenlere, müminler arasında 
alınmaktadır. Yine Vesika'nın 46. maddesi, “...Kurallara mutlaka uyulacak ve asla aykırı hareket edilmeyecektir..." ifadesiyle de Vesika'nın hükümlerinin herkes için eşit derecede bağlayıcı olduğunu düzenlemektedir ${ }^{134}$.

Ancak hukukun üstünlüğü, kuralların herkese eşit bir şekilde uygulanmasını gerektirmesinin yanı sıra, kişinin egemenliğinin ya da yönetiminin karşıtı olarak, hukukun yönetimini de gerektiriri ${ }^{135}$. Diğer bir ifadeyle hukukun üstünlüğü, iktidar üzerinde amaçlanan kısıtlamaların ve iktidarın denetlenmesi gereğinin bir tezahürüdür. $\mathrm{Bu}$ yönüyle yukarıda açıklanmaya çalış1lan $23,36 / a$ ve 42 . maddeler göstermektedir ki yürütmeye ilişkin önemli konularda ve bazı hukuki uyuşmazlıklarda son sözü söyleme yetkisi Hz. Peygamber'e aittir ${ }^{136}$. Hukuk kurallarının uygulanması anlamında hukukun üstünlüğü müessesesi Vesika'da yer bulmuş olmasına karşın; kuvvetlerin farklı devlet organlarına verilmesi, kuralların iktidarı sınırlandırması ve bireyleri koruması konusunda, siyasi iktidarın üstünlügü söz konusudur. Kaldı ki kuralların herkese uygulanmasını denetleyecek bir kurum da mevcut değildir. Ayrıca unutulmaması gerekir ki, kuvvetlerin ayrılmadığı toplumlarda hukukun değil, er geç iktidarın üstünlüğü ortaya çıkar. Konuya Hz. Peygamber açısından değil, ileri sürüldüğü gibi Vesika'nın anayasa olduğu iddiası açısından bakıldığında Vesika'nın yetersiz kaldığını söylemek gerekir.

Vesika'nın değerlendirilmesine ilişkin diğer konu ise birey hak ve hürriyetlerinin korunup korunmadığıdır. Vesika'nın 16. maddesindeki "Yahudilerden bize tâbi olanlar, zulme uğramadan ve onların düşmanlartyla yardımlaşmadan yardımımıza hak kazanacaktır." ifadesi, devlete egemen unsurun Müslümanlar olduğunu göstermesinin yanında, devlet iktidarının himayesinde yer alan, yani Vesika'nın 25/a maddesinde belirtildiği üzere "ümmet" olan Yahudilerin zulümden emin kılındıklarını ve haklarına riayet edileceğini de göstermektedir ${ }^{137}$. İlaveten Vesika'nın 25/a maddesinde, Müslümanların iktidar olduğu Medine'de, vatandaşların din ve vicdan hürriyeti açıkça kabul edilmiştir. Buna göre Müslümanlarla birlikte Yahudi vatandaşların da diledikleri gibi inanmaları ve ibadet etmeleri güvence altına

karışıklık çıkarmak isteyen kimselere karşı olacak ve bunlardan biri kendilerinden bir kişinin evlâdı bile olsa hepsinin elleri onun aleyhine kalkacaktır."

134 Bkz. Armağan, s. 190-110; Özkan, s. 51.

135 Butler, s. 136; Rijpkema, s. 795; Eren, Anayasa Hukuku, s. 207.

${ }^{136}$ Benzer yönde bkz. Koyuncu, s. 98.

${ }^{137}$ Bkz. Armağan, s. 112; Güneş, s. 214; Özkan, s. 48; Emon, s. 106. 
alınmaktadır ${ }^{138}$. Vesika'da yaşam hakkına ilişkin diyetler, haklara yönelen haksız fiiller ve iç karışıklık meselelerinin yanı sıra; vatandaşlara düşen askeri veya ekonomik yükümlülükler de yer almaktadır ${ }^{139}$. Dolayısıyla temel bazı hürriyetlerin belli oranda güvence altına alındığını ve bu hürriyetleri korumaya ilişkin devletin ve siyasi iktidarın sorumlu olduğunu söylemek yanlış olmaz. Ne var ki burada toplumun alt grupları arasında bireycilikten bağımsız bir tür mutabakatın olduğu söylenebilir ve insan hakları itibariyle bu hakların siyasi iktidar için bir ahlaki ödev mi yoksa hukuki bir sınır mı olduğunun tespiti farklı bir tartışma konusudur.

Burada belgenin yazılı olması da önemlidir ${ }^{140}$. Vesika'nın bazı maddeleri kendisine "kitap" ve "sahife" gibi ifadelerle atıfta bulunmaktadır ${ }^{141}$. Tuğ, bu ifadelerin bizzat Vesika'nın içerisinde yer almasına önemli bir anlam yüklemektedir ${ }^{142}$. Zira ona göre, Kur'an-1 Kerim'de sahife ve kitap ifadeleri peygamberlere verilen kutsal kitaplar için kullanıldığından bu tür nitelendirmeler Vesika'ya verilen değeri göstermektedir ${ }^{143}$. Ancak yüklenen bu anlamın önemi veya belgenin yazılı olması, onun anayasa olduğu anlamına gelmez. Yukarıda bahsedilen bireycilik ve iktidarı sınırlandırma hususlarının da Vesika'da yer alması gerekir. Aksi halde devlet teşkilatına ilişkin her yazılı belgeye anayasa demek gerekir.

Sonuç olarak, Vesika yazılı şekle sahip kurucu bir belgedir. Ancak Vesika'da iktidarı bölmeye ve sınırlandırmaya yönelik bir amacının olmadığı açıktır. Kaldı ki Medine İslam Devleti bir Peygamber devletidir. Müslümanlar iman etmiş haldedir ve Yahudiler de devletin siyasi iktidarı olacak kişinin, yani Hz. Peygamber' in peygamberlik sifatıyla hareket ettiğini, kendileri iman etmemiş olsa da, bilmektedirler ${ }^{144}$. Madison, günah işlemekten korunan

${ }^{138}$ Bkz. Armağan, s. 112; Koyuncu, s. 98; Güneş, s. 215; Özkan, s. 48; Emon, s. 106.

${ }^{139}$ Bkz. Vesika, madde 3, 4, 5 vd., 12, 13 ve 14. Konuya ilişkin olarak; Vesika, madde 13, "Takvâ sahibi müminler saldırganlara, haksız bir fiil tasarlayanlara ve cürüm işleyenlere, bir hakka tecavüz edenlere, müminler arasında karışıklık çıkarmak isteyen kimselere karşı olacak ve bunlardan biri kendilerinden bir kişinin evlâdı bile olsa hepsinin elleri onun aleyhine kalkacaktır." hükmü bir örnek teşkil eder. Konuya yönelik değerlendirmeler için bkz. Güneş, s. 214.

${ }^{140}$ Yazılı anayasalar ve istisna olarak teamüli bir anayasaya sahip olan İngiltere örneği için bkz. Eren, s. 8-9; Anayurt, s. 109-111.

${ }^{141}$ Vesika kendisinden, 1 ve 47. maddelerde "bu kitap" denilmek suretiyle kitap olarak, birden fazla kez ve farklı maddelerinde de "sahife" olarak bahsetmektedir.

142 Bkz. Tuğ, s. 191.

${ }^{143}$ Bkz. Tuğ, s. 191.

${ }^{144} \mathrm{~Hz}$. Peygamber'in varlığı, nitelikleri, hayatı, söz ve eylemlerinin ifade ettiği anlam anlaşılmadan Vesika'nın anlamlandırılması pek mümkün değildir. Özellikle iman edenler için Hz. Peygamber tüm diğer peygamberler gibi günah işlemekten korunmuş, masum, diğer 
varlıkların devleti yönetmesi halinde iktidarın sınırlandırılmasına veya denetlenmesine gerek olmayacağını söyler ${ }^{145}$. İslam Devleti ve Hz. Peygamber'in iktidarı tam olarak bunu ifade etmektedir. Çünkü Hz. Peygamber, İslam'1 anlatmakla ve yaymakla görevli olan ve doğrudan Allah'tan bilgi (vahiy) alan bir elçidir. Bu bakımdan Hz. Peygamber'in anayasacılık unsurlarıyla, yani güç sarhoşluğuna düşeceği endişesiyle tamamen beşerî iradenin ürünü olan kimi ilke ve kurallarla sınırlandırılmasını beklemek makul bir beklenti olmadığı gibi tüm yetkilere sahip olması da kendine özgü durum gereğince gayet normaldir ${ }^{146}$.

Şöyle ki, Vesika bir anayasa değildir; olması da beklenemez. Vesika'nın bu anlamda bir anayasa olduğunu iddia etmek, 17. ve 18. yüzyılda baskıcı ve zulmeden idareciler karşısında ortaya atılan fikirlerle, "masum" olduğuna ve vahiy ile yönlendirildiğine tam bir teslimiyetle inanılan bir peygamberin insanlar tarafından sınırlandırıldığını iddia etmek olur ki; bu tamamen kabul edilemez bir iddiadır. Zira din, peygamberlere ve dinin gereklerine iman etmeyi ve sorgulamadan teslim olmayı gerektirir. Bu bakımdan anayasalarda olması gereken iktidarın sınırlandırılması unsuru, Vesika'da yer bulmuş olamaz. Yine de Hz. Peygamberin sınırsız olduğu anlaşılmamalıdır. Hz. Peygamber de Allah'ın emirleriyle bağlıdır. Ancak bu, Vesika'nın anayasacılık bağlamında iktidarın keyfileşmesi tehdidine karşı beşerî kurallarla sınırlandırma amacının olduğunu göstermez.

Nihayet anayasalar, anayasacılık fikri çerçevesinde ortaya çıkmış, hürriyetleri korumak ve iktidarı sınırlandırmak amacıyla liberal düşünce etrafında şekillenmiştir ${ }^{147}$. Bu nedenle söz konusu dönemden itibaren, belirtilen amaçlara sahip olan metinlere anayasa demek daha doğru olur. Bazı yazarların, Vesika'nın yazılı olması ve hakları konu alması nedeniyle anayasa sayılabileceğini iddia etmesi, kanaatimizce Vesika'nın amaçları da dikkate alınınca ne İslam'daki peygamber inancına ne de tarihi gerçeklere ve

bir ifadeyle günahsız bir kuldur. Konuya ilişkin ayrıca bkz. Mehmet Bulut, "İsmet", TDV Íslam Ansiklopedisi, C. 23, İstanbul 2001, s. 134-136 ss. 134-136; Fatma Günaydın, "İlk Dönem Tefsir ve Hadis Literatüründe İsmet İnancı", Kelam Araştırmaları Dergisi, C. 15, S. 1, Y. 2017, s. 2.

145 "If angels were to govern men, neither external nor internal controuls on government would be necessary." Türkçesi; "Eğer melekler insanları yönetmiş olsaydı, iktidarın ne iç ne de dış denetimine gerek kalırdı.” Bkz. James Madison, The Federalist (İçinde) (J. R. Pole Ed.), Hackett Publishing Company, Indianapolis/Cambridge 2005, No 51, s. 281.

146 Benzer yönde bkz. al-Hibri, "Islamic Constitutionalism", s. 20.

${ }^{147}$ Eren, Anayasa Hukuku, s. 1; Anayurt, Anayasa Hukuku, s. 39; Oder, s. 37; Teziç, Anayasa, s. 161. 
gelişmelere uygundur ${ }^{148}$. Buna karşılık kanaatimizce ilk yazılı anayasa, anayasacılık sonucu ortaya çıkan 1787 Amerika Birleşik Devletleri Anayasası' ${ }^{1}{ }^{149}$.

Anayasacılık unsurlarından mahrum herhangi bir metne geniş veya dar anlamda anayasa demek doğru değildir. Geniş anlamıla devlete ve bireyin haklarına ilişkin olan, 17. ve 18. yüzyıldan önceki belgelere, "anayasa benzeri" veya "anayasal nitelikli" kanun (belge, metin vb.) demek daha yerinde olur.

\section{SONUÇ}

Anayasacılık, iktidarın keyfi kararlar almasını ve kişinin yönetiminin ortaya çıkmasını engellemeyi; birey ve haklarının korunmasını gerektirir. Bunun için de temel iki unsura sahiptir. Birincisi kuvvetler ayrılı̆̆ıdır. Kuvvetler ayrılığı egemenlikten kaynaklanan yetkilerin farklı devlet organlarına verilmesini ve bu organların kendi yetki alanlarında kalarak diğer organları denetlemelerini gerektirir. Bu sayede yetkilerin sinırsız ve keyfi olarak kullanılmasının önlenmesi amaçlanır. İkincisi ise hukukun üstünlüğüdür. Hukukun üstünlüğü en sade haliyle hukuk kurallarının herkes için bağlayıcı olmasını, kuralların açık ve öngörülebilir olması gibi bazı niteliklere sahip olmasını ve kuralların adil olmasını gerektirir. Aynı zamanda devlet organlarının denetlenmesi de hukukun üstünlüğünün gereklerindendir. Anayasacılığın bu unsurları ve teorik temelleri ise liberal düşüncenin etkisiyle gelişmiştir. Diğer bir ifadeyle, büyük oranda 17. yüzyılda ortaya çıkmaya başlamıştır. Bu nedenle, anayasacılık düşüncesini, kurumsallık kazandığ yüzyıldan önceki uygulamalarla karıştırmamak gerekir.

Anayasacılık açısından anayasa kavramına bakıldığında ise anayasalar, ilk olarak 18. yüzyılda ortaya çıkmıştır. Yani anayasalar, anayasacılık düşüncesinin ve modern zamanların kavramıdır. Bu çerçevede anayasanın muhtevası ve niteliği 17 . yüzyıldan itibaren yaygınlaşan anayasacılık

${ }^{148}$ Aksi yönde görüş ve iddialar için bkz. Özkan, s. 43-44.

${ }^{149}$ Eren, Anayasa Hukuku, s. 9; Gözler, Anayasa Hukuku, s. 69; Anayurt, Anayasa Hukuku, s. 109. İngiliz gelenekselliği ve devrimleri bağlamında gelişen iktidarın sınırlandırılması düşüncesi; bu düşünceyi esas alan yazılı metinlerden ve yazılı olmayan teamüllerden anayasa olarak bahsetmek yerindedir. Nitekim anayasacılık düşüncesi etrafında siyasi iktidarın sınırlandırılmasına yönelik 17. yüzyılda ortaya çıkan devrimler ve bildiriler İngiltere'de Kral'a karşı gelişmiştir. Bu mücadeleler sonrasında da bireysel hürriyetlerin korunması ve kral karşısında parlamentonun güç kazanması söz konusu olmuştur. Dolayısıyla İngiltere'de geleneksel anayasa olduğundan söz etmek gerekir. Bu anayasa ABD Anayasasından daha önce gelişmiştir. 
hareketleri çerçevesinde belirginlik ve karakter kazanmıştır. Anayasaların da bu gelişime uygun olarak tanımlanması gerekir. Netice olarak, anayasaların geniş ve dar anlamda ayrılmalarından ziyade, anayasacılık açısından önemli olan anayasaların işlevleridir. Anayasaların işlevi ise birey hürriyetlerinin korunması adına iktidarların sınırlandırılmasıdır. Başka bir deyişle anayasacılık ve sonucunda ortaya çıkan anayasalar, devleti ve toplumu oluşturan temel birimin birey olduğunun ve onun karşısında her şeyin ikincilliğinin ilanıdır.

Medine Vesikası'na bakıldığında ise Vesika'da devletin yapısı ve teşkilatının düzenlenmesinin yanı sıra birey hak ve yükümlülüklerine, diğer bir ifadeyle maddi anlamda anayasal konulara yer verildiği görülmektedir. Ancak Vesika'nın incelenmesi halinde bu konulara yer verilmesinin nedeninin, siyasi bir organizasyonun kurulması aşamasında toplumu meydana getiren farklı dini grupların birlik oluşturabilmesini sağlamak olduğu söylenebilir. Başka bir ifadeyle, bu konulara yer verilmesi amacının iktidarı sınırlandırmak değil, toplumun ahengini sağlamak olduğunu belirtmek gerekir.

Bununla birlikte Vesika'ya veya 17. yüzyıl öncesine ait tüm yazılı ve yazısız kurallara ilişkin sorun, konularının anayasal nitelikte olup olmaması değildir. Yazılı veya yazısız, ilk topluluklardan beri anayasal nitelikli kurallar mevcuttur. Bir toplulukta bu tür kuralların olmamasını düşünmek ise pek mümkün değildir. Ne var ki bu yazılı ve yazısız kurallar bütünü, özelde ise Vesika anayasa mıdır sorusu diğer başka bir problemdir.

Anayasalar bireyin teminatı, iktidarın da sınırıdır. Melekler veya günahsızlar tarafindan yönetilmeyen, her an hataya düşebileceğine inanılan beşerî varlıkların yönetimi karşısında hürriyetlerin bekçisidir. Oysa iktidarın sınırlandırılması bağlamında, iktidarın güvenilemez olduğu düşüncesine Vesika'da rastlamak mümkün değildir. Bu kanaatimizce anayasa kavramının, anayasacılıktan ve ortaya çıkış zamanından bağımsız açıklanamaz olmasıyla ilgilidir. Vesika, bir anayasada mutlaka olması gereken bireycilik düşüncesine ve iktidarın sınırlandırılması amacına sahip değildir. Nitekim bu tür endişelerden uzak, toplumsal iş birliği ve ahengi sağlamak, siyasi birliği oluşturmak ve diş saldırılara karşı içeride bir güvence sistemi kurmak amaciyla, günah işlemeyeceğinden emin olunan $\mathrm{Hz}$. Peygamber önderliğinde hazırlanmıştır. Netice itibariyle Vesika'nın Hz. Peygamberi sınırlandırmak ve O'nun keyfi davranışlarına karşı bireyleri korumak için hazırlandığını iddia etmek doğru değildir. Vesika, yalnızca temel bazı meseleleri düzenlemekte, hukuki bir metin olmasının yanı sıra anayasa olma vasfını taşımamaktadır. $\mathrm{Bu}$ 
bağlamda farklı dini gruplar arasında yapılan bir tür sözleşme olduğu da göz ard1 edilmemelidir.

Son olarak belirtmek gerekir ki, her ne kadar anayasacılık Batı kaynaklı olsa da, bu durum İslam devletlerinin kendi değer ve hassasiyetlerine uygun olarak anayasacılık düşüncesini benimsemesine engel değildir. Siyasi iktidarın çeşitli yönlerden sınırlı olduğunu kabul ettiğimizde, İslam'ın gereklerine aykırı olmayacak şekilde anayasacılığa uygun bir yönetim kurulabilir ve anayasa yapılabilir.

\section{KAYNAKÇA}

AKYOL, Taha, Türkiye'nin Hukuk Serüveni, 5. Bs., Doğan Kitap, İstanbul 2016.

AL-HIBRRI, Azizah, "Islamic and American Constitutional Law: Borrowing Possibilitiesor a History of Borrowing?", Islamic and American Constitutional Law, C. 1, S. 2, Y. 1999. (ss. 492-527).

AL-HIBRI, Azizah, "Islamic Constitutionalism and the Concept of Democracy", Case Western Reserve Journal of International Law, C. 24, S. 1, Y. 1992. (ss. 127).

ALİ HAYDAR EFENDİ, Hocaeminefendizâde, Dürer'ül- Hükkâm Şehru Mecelleti'l-Âhkam, C. I, 1. Bs., Diyanet İşleri Başkanlığı Yayınları, İstanbul 2016.

ANAYURT, Ömer, Anayasa Hukuku Genel Kısım, 2. Bs., Seçkin Yayıncılık, Ankara 2019.

ANSAY, Sabri Şakir, Hukuk Tarihinde İslam Hukuku, 2. Bs., Ankara Üniversitesi İlahiyat Fakültesi Yayınları, Ankara 1954.

ANSAY, Sabri Şakir, Hukuk Tarihinde İslam Hukuku, 4. Bs., Turhan Kitabevi, Ankara 2002.

ARMAĞAN, Servet, “Ilk Yazılı Anayasa: Medine Vesikası", 2016-2017 Siyer Mektebi Müfredatı-İman Şehri Medine (7. Ders), http://www.siyervakfi.org/ilkyazili-anayasa-medine-vesikasi-prof-dr-servet-armagan/ (E. 25.06.2020).

ARSLAN, Zühtü, Anayasa Teorisi, 1. Bs., Seçkin Yayıncılık, Ankara 2008.

ATÇEKEN, İsmail Hakkı, "İslam Tarihinde Bir Arada Yaşama Tecrübesi (Asr-1 Saadet ve Endülüs Örneği)”, İSAM, S. 14, Y. 2007. (ss. 41-59).

BACKER, Cata, "From Constitution to Constitutionalism: A Global Framework for Legitimate Public Power Systems", Penn State Review, C. 113, S. 3, Y. 2009. (ss. 671-732). 
BILLIAS, George Athan, American Constitutionalism Heard Round the World 17761989, 1. bs., New York University Press, New York-London 2009.

BULUT, Mehmet, “İsmet”, TDV İslam Ansiklopedisi, C. 23, İstanbul 2001. (ss. 134136).

BUTLER, Eamonn, Özgür Toplumun Temelleri (Çev. Hakan Şahin), 1. Bs., Liberte Yayınları, Ankara 2016.

CEYLAN, Ayhan, “İslam'da Siyasi İktidar”, EÜHFD, C. VII, S. 1-2. (“İktidar”) (ss. 89-104).

ÇELIKKER, Hüseyin, “İslam Hukuku'nda Devlet Başkanlığı”, Ondokuz Mayıs Üniversitesi İlahiyat Fakültesi Dergisi, C. 26, S. 26-27, Y. 2008. (ss. 251-298).

DEMIRCİ, Abdurrahman, "Medine Vesikasi: Oluşum Süreci ve Zimmet Anlaşmalarına Etkisi”, İstem, S. 19, Y. 2012. (ss. 253-271).

EBU ZEHRA, Muhammed, İslam Hukuku Metodolojisi-Fıkıh Usûlü, (Çev. Abdulkadir Şener), 13. Bs., Fecr Yayınları, Ankara 2017.

EMON, Anver, "Reflections on The "Constitution of Madina" an Essay on Methodology and Ideology in Islamic Legal History", Journal of Islamic and Near Eastern Law, S. 103, Y. 2001. (ss. 103-133).

ERDEM, Fazıl Hüsnü, “Anayasal Vatandaşlık ve Yeni Anayasa”, Liberal Düşünce, S. 66, Y. 2012. (ss. 49-56).

ERDOĞAN, Mustafa, Anayasacılık-Parlamantarizm-Silahlı Kuvvetler, 1. Bs., Siyasal Kitabevi, Ankara 1993. (Anayasacılık).

ERDOĞAN, Mustafa, Anayasal Demokrasi,13. Bs., Siyasal Kitabevi, Ankara 2017. (Anayasal Demokrasi).

EREN, Abdurrahman, Anayasa Hukuku Ders Notları, On İki Levha Yayıncılık, İstanbul 2018.

FENDOĞLU, Hasan Tahsin, İslam ve Osmanlı Anayasa Hukukunda Yargı Bağımsızlığı, 1. Bs., Beyan Yayınları, İstanbul 1996.

FLANZ, Gisbert H., XIX. Asır Avrupasında Anayasa Hareketleri (Çev. Necat Erder/Şerif Mardin/Aydın Sinanoğlu), 1. Bs., AÜSBF Yayınları/Müşterek Yayınlar, Ankara 1956.

FRIEDRICH, Carl, Sınırlı Devlet (Çev. Mehmet Turhan), 2. Bs., Liberte Yayınları, Ankara 2014.

GÖZLER, Kemal, Anayasa Hukukunun Genel Esasları, 8. Bs., Ekin Yayınları, Bursa 2016. (Anayasa Hukuku).

GÖZLER, Kemal, Anayasa Hukukunun Genel Teorisi, C. I, 1. Bs., Ekin Basım, Bursa 2011. (Teori I). 
GÖZLER, Kemal, "İslâm Hukukunun Değeri: İslâm Hukuku, Batı Hukukuna Alternatif Olabilir mi?", www.anayasa.gen.tr/islam-hukuku.htm, 16 Aralık 2019, (E. 25.06.2020).

GRIMM, Dieter, Constitutionalism Past, Present and Future, 1. Bs., Oxford University Press, New York 2016.

GÜL, Cengiz, İktidarın Sınırlandırılması ve Hukuk Devleti, 1. Bs., Adalet Yayınevi, Ankara 2010.

GÜNAYDIN, Fatma, “İlk Dönem Tefsir ve Hadis Literatüründe İsmet İnanc1”, Kelam Araştırmaları Dergisi, C. 15, S. 1, Y. 2017. (ss. 1-28).

GÜNEŞ, Ahmet, "Medine Vesikası'nın İslam Hukuku Açısından Kaynak Değeri”, EKEV Akademi Dergisi, S. 34, Y. 2008 (Kış). (ss. 211-222).

HAMIDULlAH, Muhammed, Hemmam İbn Munebbih'in Sahifesi (Çev. Talat Koçyiğit), Ankara Üniversitesi Basımevi, Ankara 1967. (Hemmam İbn Munebbih'in Sahifesi).

HAMIDULLAH, Muhammed, İslam Anayasa Hukuku, Beyan Yayınları, İstanbul 2018. (İslam Anayasa Hukuku).

HAMIDULLAH, Muhammed, İslam Peygamberi (Çev. Salih Tuğ), C. I, Yeni Şafak, Ankara 2003. (İslam Peygamberi).

HAYEK, Friedrich A., The Constitution of Liberty, 1. Bs., The University of Chicago Press, Chicago 1978. (The Constitution).

HİMETLİ, Sabri, İslam Tarihi, Ankara Üniversitesi İlahiyat Fakültesi Yayınları, Ankara 1991.

Hz. Ali/Ebu Yusuf/ZEYDAN, Abdülkerim, İslam'da Ferd ve Devlet Münasebetleri, 2. Bs., Kayıhan Yayınevi, İstanbul 1995.

IBN ASHUR, Muhammed Al-Tahir, Treatise on Maqasid al-Shari'ah, 1. Bs., Biddles, London-Washington 2006.

ORTAYLI, İlber, Hukuk ve İdare Adamı Olarak Osmanlı Devleti'nde Kadı, Kronik Kitap, 7. Bs., İstanbul 2017.

İLHAN, Cengiz, Günümüz Türkçe'siyle Mecelle, 2. Bs., Yetkin Yayınları, Ankara 2014.

KABOĞLU, İbrahim O., Anayasa Hukuku Dersleri, 9. Bs., Legal Yayınc1lı, İstanbul 2014.

KARAMAN, Hayrettin, Mukayeseli İslam Hukuku, C. 1, 1. Bs., İz Yayıncılık, İstanbul 2013.

KARAYALÇIN, Yaşar, "Hukukun Üstünlüğü (Kavram-Bazı Problemler)", Hukuk Devleti (İçinde) (Haz. Hayrettin Ökçesiz), 1. Bs., AFA Yayınları, İstanbul 1998. (ss. 117-146). 
KESKINN, Erdoğan, Anayasa Hukukunda Anayasacılık Düşüncesi, Adalet Yayınevi, Ankara 2020.

KOYUNCU, Mevlüt, "Medine Devleti”, Sakarya Üniversitesi Fen Edebiyat Dergisi, C. 11, S. 2, Y. 2009. (ss. 87-103).

KUBALI, Hüseyin Nail, Anayasa Hukuku Genel Esaslar ve Siyasi Rejimler, Ersa Matbaacilık, İstanbul 1965. (Genel Esaslar).

KÜÇÜK, Eşref, "Eski Roma'da Cumhuriyet Dönemi Halk Meclisleri ve Yasa Yapım Süreçleri”, Hacettepe Hukuk Fakültesi Dergisi, C. 7, S. 1, Y. 2017. (ss. 199214).

LEVY, Jacob T., "Montesquieu's Constitutionalism Legacies", Montesquieu and His Legacy (İçinde) (Rebecca E. Kingston Ed.), 1. Bs., Suny Press, Albany 2009, https://papers.ssrn.com/sol3/papers.cfm?abstract_id=1117087 (E. 25.06.2020).

MADISON, James, The Federalist (İçinde) (J. R. Pole Ed.), Hackett Publishing Company, Indianapolis/Cambridge 2005.

MARTIN, Brian, "Power Tends to Corrupt", Philosophy and Social Action, C. 16, S. 3, Y. 1990.

MCILWAIN, Charles Howard, Constitutionalism: Ancient and Modern (e-book), Revised Edition, Cornell University Press, New York 1947. (Constitutionalism).

MCILWAIN, Charles Howard, The High Court of Parliament and Its Supremacy, 1. Bs., Yale University Press, London 1921.

MONTESQUiEU, Kanunların Ruhu Üzerine (Çev. Şevki Özbilen), Seçkin Yayınc1lık, İstanbul 2014.

ODER, Bertil Emrah, Avrupa Birliği'nde Anayasa ve Anayasacılık, 1. Bs., Anahtar Kitaplar Yayınevi, İstanbul 2004.

OKİÇ, Tayyib, “İslamiyet’te İlk Nüfus Sayımı", Ankara Üniversitesi İlahiyat Fakültesi Dergisi, C. 7, S. 1, Y. 1958. (ss. 12-20).

OSMAN, Fethi, Düşünce Devleti, Fecr Yayınları, Ankara 1992.

ÖZBUDUN, Ergun, Anayasalc1lık ve Demokrasi, 1. Bs., İstanbul Bilgi Üniversitesi Yayınları, İstanbul 2015.

ÖZKAN, Mustafa, Medine Vesikası/Anayasası ve Birlikte Yaşam, Fecr Yayınları, Ankara 2018.

RICHARDS, David A. J., Foundations of American Constitutionalism, 1. Bs., Oxford University Press, New York-Oxford 1989.

RIJPKEMA, Peter, "The Rule of Law Beyond Thick and Thin”, Law and Philosophy, S. 32, Y. 2013.

RUHI, Muhammet Emin, 1789 Fransız Devrimi Birinci Kitap, 1. Bs., On İki Levha Yayınc1lı, İstanbul 2018. 
SAFA, Mustafa, "Hicret Sonrasında Medine'de Sosyal ve Dini Hayat", Toplum Bilimleri Dergisi, C. 9, S. 17. (ss. 355-398).

ŞAFIII, Ebû Abdullah Muhammed b. İdris, Kitabu'l-ümm, I-VIII, C. I, Beyrut. (Aktaran: ÇELIKKER, Hüseyin, "İslam Hukuku'nda Devlet Başkanlığı").

SARTORI, Giovanni, "Constitutionalism: A Preliminary Discussion", The Political Science Review, C. 56, S. 4, Y. 1962.

ŞAHIN, Adil, "Siyasal Düşünceler Tarihinde "Sınırlı Devlet" Fikrinin Kadimliği ya da Genel Kamu Hukuku Bağlamında İnsan, Özgürlük ve Devlet İktidarı Algısında Evrilme", Gazi Üniversitesi Hukuk Fakültesi Dergisi, C. XV, S. 3, Y. 2011. (ss. 311-362).

TANILLİ, Server, Dünyayı Değiştiren 10 Yı1, 2. bs., Adam Yayıncılık, İstanbul 1999.

TEZİÇ, Erdoğan, Anayasa Hukuku, 20. Bs., Beta Basım, İstanbul 2016.

TUĞ, Salih, İslam Ülkelerinde Anayasa Hareketleri, İrfan Yayınevi, İstanbul 1969.

TURHAN, Mehmet, “Anayasa ve Anayasacıllk”, Amme İdaresi Dergisi, C. 27, S. 3 , Y. 1994. (ss. 3-12). ("Anayasa ve Anayasacilık").

TURHAN, Mehmet, Anayasal Devlet, 3. Bs., Natural Yayıncılık, Ankara 2004. (Anayasal Devlet).

UZUNÇARŞILI, İsmail Hakkı, Osmanlı Devleti’nin İlmiye Teşkilatı, 4. Bs., Türk Tarih Kurumu, Ankara 2014.

VURAL, Muammer, "Yasama Kavramı ve Yetkisi Açısından Pozitif Hukuk ile İslâm Hukuku Arasında Bir Mukayese", Atatürk Üniversitesi İlahiyat Fakültesi Dergisi, S. 36, Y. 2011. (ss. 177-200).

WHEARE, K. C., Modern Anayasalar (Çev. Mehmet Turhan), Değişim Yayınları, İstanbul 1984.

YAVUZ, Y. Vehbi, “İcma'ın Hakikati ve İslam Teşri'indeki Önemi”, İslam Hukuku Araştırmaları Dergisi, S. 3, Y. 2004. (ss.85-112).

YÜKSEL, Mehmet, "Osmanlı Toplum Yapısında Şeyhülislamlık Makamına Bir Bakış”, MÜHFHAD Cevdet Yavuz'a Armağan, C. 22, S. 3, Y. 2016.

\section{İnternet Kaynakları:}

http://ahmetsimsirgil.com/wp-content/uploads/2015/12/Veda-Hutbesi.pdf 25.06.2020)

http://www.agc.gov.my/agcportal/uploads/files/Publications/FC/Federal\%20Consti $\% 20$ (BI\%20text).pdf (E. 25.06.2020).

https://www.phrases.org.uk/meanings/absolute-power-corrupts-absolutely.html (E. 25.06.2020).

https://encyclopedia.ushmm.org/content/tr/article/third-reich-an-overview 25.06.2020).

(E. 